\title{
Eastern Beringia and beyond: Late Wisconsinan and Holocene landscape dynamics along the Yukon Coastal Plain, Canada
}

\author{
Michael Fritz a,*, Sebastian Wetterich a , Lutz Schirrmeister ${ }^{a}$, Hanno Meyer ${ }^{\text {a }}$, Hugues Lantuit ${ }^{\text {a }}$, \\ Frank Preusser ${ }^{b}$, Wayne H. Pollard ${ }^{\mathrm{c}}$ \\ a Alfred Wegener Institute for Polar and Marine Research, Department of Periglacial Research, Telegrafenberg A43, 14473 Potsdam, Germany \\ b Stockholm University, Department of Physical Geography and Quaternary Geology, 10691 Stockholm, Sweden \\ ${ }^{c}$ McGill University, Department of Geography, 805 Sherbrooke St. West, H3A2K6 Montreal, Quebec, Canada
}

\section{A R T I C L E I N F O}

\section{Article history:}

Received 21 April 2011

Received in revised form 16 December 2011

Accepted 22 December 2011

Available online $\mathrm{xxxx}$

\section{Keywords:}

Laurentide Ice Sheet

Beringia

Permafrost

Herschel Island

Ground ice

Stable water isotopes

\begin{abstract}
A B S T R A C T
Terrestrial permafrost archives along the Yukon Coastal Plain (northwest Canada) have recorded landscape development and environmental change since the Late Wisconsinan at the interface of unglaciated Beringia (i.e. Komakuk Beach) and the northwestern limit of the Laurentide Ice Sheet (i.e. Herschel Island). The objective of this paper is to compare the late glacial and Holocene landscape development on both sides of the former ice margin based on permafrost sequences and ground ice. Analyses at these sites involved a multi-proxy approach including: sedimentology, cryostratigraphy, palaeoecology of ostracods, stable water isotopes in ground ice, hydrochemistry, and AMS radiocarbon and infrared stimulated luminescence (IRSL) dating. AMS and IRSL age determinations yielded full glacial ages at Komakuk Beach that is the northeastern limit of ice-free Beringia. Herschel Island to the east marks the Late Wisconsinan limit of the northwest Laurentide Ice Sheet and is composed of ice-thrust sediments containing plant detritus as young as $16.2 \mathrm{cal}$ ka BP that might provide a maximum age on ice arrival. Late Wisconsinan ice wedges with sediment-rich fillings on Herschel Island are depleted in heavy oxygen isotopes (mean $\delta^{18} \mathrm{O}$ of $-29.1 \%$ ); this, together with low $d$ excess values, indicates colder-than-modern winter temperatures and probably reduced snow depths. Grain-size distribution and fossil ostracod assemblages indicate that deglaciation of the Herschel Island icethrust moraine was accompanied by alluvial, proluvial, and eolian sedimentation on the adjacent unglaciated Yukon Coastal Plain until 11 cal ka BP during a period of low glacio-eustatic sea level. The late glacial-Holocene transition was marked by higher-than-modern summer temperatures leading to permafrost degradation that began no later than $11.2 \mathrm{cal}$ ka BP and caused a regional thaw unconformity. Cryostructures and ice wedges were truncated while organic matter was incorporated and soluble ions were leached in the thaw zone. Thermokarst activity led to the formation of ice-wedge casts and deposition of thermokarst lake sediments. These were subsequently covered by rapidly accumulating peat during the early Holocene Thermal Maximum. A rising permafrost table, reduced peat accumulation, and extensive ice-wedge growth resulted from climate cooling starting in the middle Holocene until the late 20th century. The reconstruction of palaeolandscape dynamics on the Yukon Coastal Plain and the eastern Beringian edge contributes to unraveling the linkages between ice sheet, ocean, and permafrost that have existed since the Late Wisconsinan.
\end{abstract}

(c) 2011 Elsevier B.V. All rights reserved.

\section{Introduction}

During the Last Glacial Maximum (LGM, 22 to 19 cal ka BP), Alaska and the Yukon constituted the eastern margin of Beringia (Hultén, 1937; Hopkins, 1982; Harington, 2005). This unglaciated region extended westward across the Bering land bridge into Siberia when the glacio-eustatic sea level was $\sim 120$ m lower than today

\footnotetext{
* Corresponding author. Tel.: +49331 288 2168; fax: + 493312882188.

E-mail addresses: Michael.Fritz@awi.de (M. Fritz), Sebastian.Wetterich@awi.de (S. Wetterich), Lutz.Schirrmeister@awi.de (L. Schirrmeister), Hanno.Meyer@awi.de (H. Meyer), Hugues.Lantuit@awi.de (H. Lantuit), frank.preusser@natgeo.su.se (F. Preusser), wayne.pollard@mcgill.ca (W.H. Pollard).
}

(Fairbanks, 1989; Yokoyama et al., 2000). The region was affected by severe periglacial processes during the late Quaternary, creating landforms that can be used to reconstruct Glacial-Interglacial dynamics of landscape and climate. The Yukon Coastal Plain (YCP), in the western Canadian Arctic, is situated at the interface of the formerly glaciated terrain and the easternmost margin of Beringia to the west. It therefore contains a terrestrial environmental record that is preserved in permafrost. These permafrost archives have recorded strong environmental gradients in the past; some parts having been ice-covered during the Wisconsinan ( 115 to $10 \mathrm{ka} \mathrm{BP})$, while others remained ice-free, immediately adjacent to the Laurentide Ice Sheet (LIS) to the east. Despite its outstanding position and relevance to the understanding of regional landscape development along the ice 
sheet margin, the region and its late Quaternary history are addressed by only a few records which focus on permafrost sequences and related glacial deposits (Bouchard, 1974; Rampton, 1982; Harry et al., 1988).

Additional studies have been carried out since the 1970s focusing on lake sediments covering the northern Yukon (e.g. Rampton, 1971; Cwynar, 1982; Ritchie and Cwynar, 1982; Lacourse and Gajewski, 2000; Pienitz et al., 2000; Kurek et al., 2009; Vermaire and Cwynar, 2010), the Northwest Territories (e.g. Ritchie and Hare, 1971; Ritchie et al., 1983; Spear, 1993; Cwynar and Spear, 1995), and adjacent Alaska (e.g. Anderson, 1985, 1988; Eisner and Colinvaux, 1990; Anderson et al., 1994; Berger and Anderson, 1994; Ager, 2003; Abbott et al., 2010). These have been used to reconstruct climatedriven vegetation changes and past temperature regimes. Permafrost and ground-ice investigations have also been carried out to reconstruct past environmental dynamics such as ground ice origin (e.g. Mackay, 1971; Pollard and Dallimore, 1988; Pollard, 1990; Mackay and Dallimore, 1992; Lacelle et al., 2004, 2007, 2009; Murton et al., 2004, 2005), sediment transport processes (e.g. Carter, 1981; Lauriol et al., 2002; Bateman and Murton, 2006; Murton and Bateman, 2007), peatland development (e.g. Eisner, 1991; Vardy et al., 1997, 1998, 2000; Eisner et al., 2003), and vertebrate and invertebrate palaeoecology (e.g. Matthews, 1975; Delorme et al., 1977; Nelson and Carter, 1987; Matthews et al., 1990; Hamilton and Ashley,
1993; Hamilton et al., 1993; Zazula et al., 2009). However, most of these studies have been conducted at sites (Fig. 1 and Table 1) that are located either within the LIS margin or far inland, beyond the influence of the Arctic Ocean. Hence, they are less representative of environmental conditions of coastal Beringia, especially the YCP and adjacent Arctic Coastal Plain of Alaska (Ayles and Snow, 2002).

This study ascertains and compares the Late Wisconsinan and Holocene landscape development on both sides of the former LIS margin along the YCP based on permafrost sequences and ground ice. Its specific objectives include to trace permafrost aggradation and degradation (thermokarst) history under changing depositional environments by describing the cryostratigraphy, analyzing the sediment texture, dating the sediment sequences and measuring the stable $\mathrm{O}-\mathrm{H}$ isotope composition of ground ice. With the help of analytical results and field observations we aim at differentiating and comparing significant stages in landscape development within (Herschel Island) and beyond (Komakuk Beach) the LIS limit.

\section{Study area}

The YCP is the landward extension of the Beaufort continental shelf and is covered with Pleistocene and Holocene unconsolidated deposits assigned to the Gubik Formation (Black, 1964; Dinter et al., 1990; Brigham-Grette and Carter, 1992). The YCP extends about

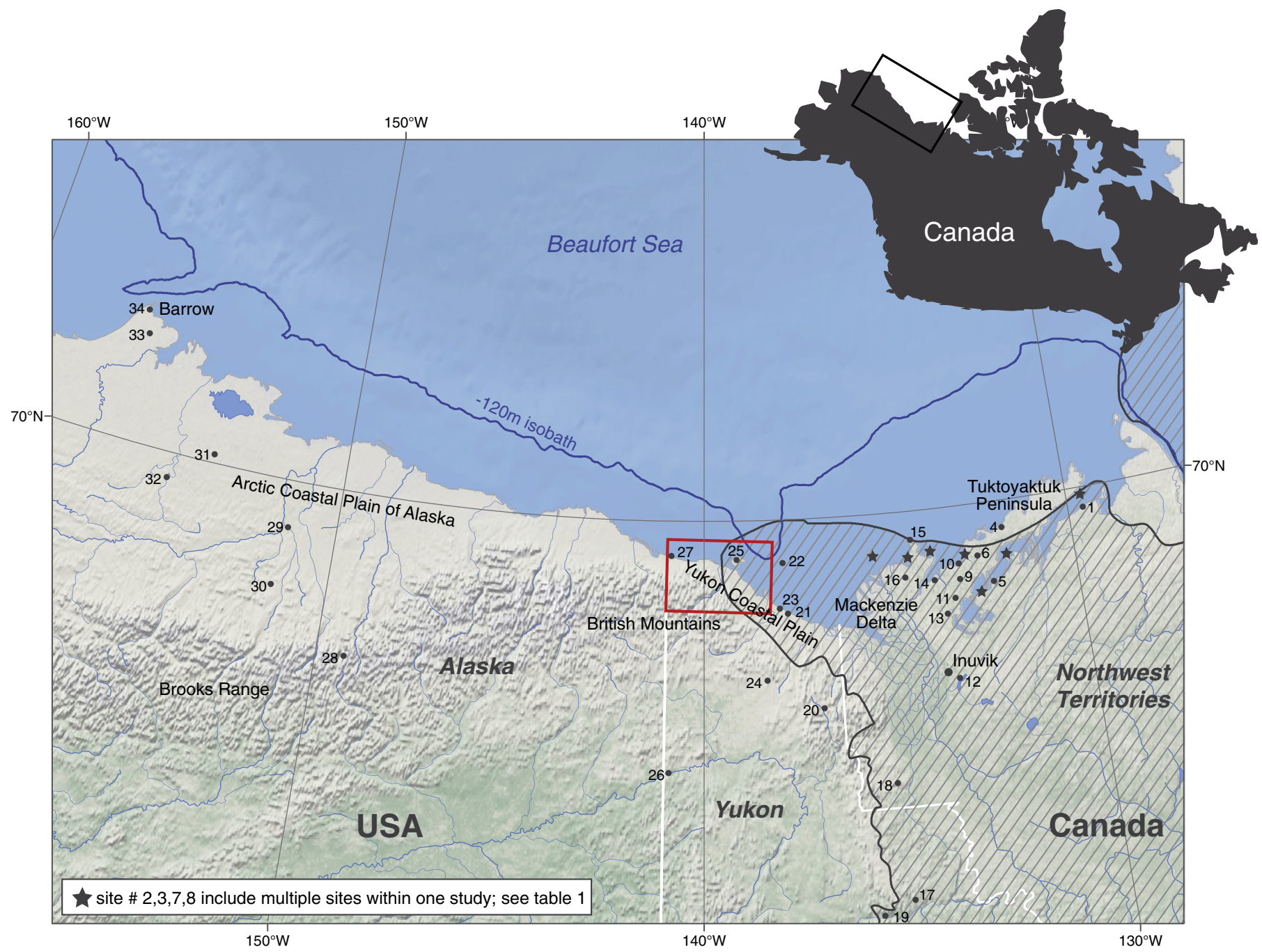

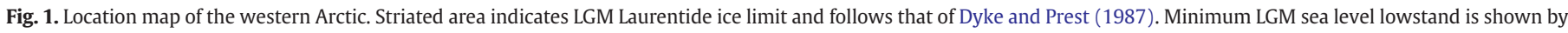

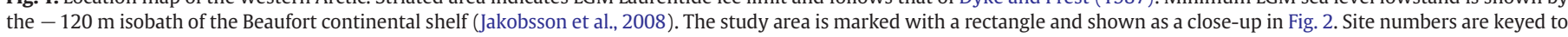
Table 1. 
Table 1

Key to Fig. 1 and references mentioned in the text to show the distribution and age range of palaeoenvironmental archives related to findings from the Yukon Coastal Plain.

\begin{tabular}{|c|c|c|c|c|c|c|c|}
\hline $\begin{array}{l}\text { Site } \\
\text { ID }\end{array}$ & Site name & $\begin{array}{l}\text { Long } \\
{\left[{ }^{\circ} \mathrm{W}\right]}\end{array}$ & $\begin{array}{l}\text { Lat } \\
{\left[{ }^{\circ} \mathrm{N}\right]}\end{array}$ & Archive type & Proxy (predominant) & $\begin{array}{l}\text { Age of record } \\
{[\mathrm{ka}]}\end{array}$ & Citation \\
\hline 1 & Cliff Point & 129.15 & 69.80 & Permafrost & Geochronology & $\sim 24(\mathrm{OSL})$ & Murton et al. (2007) \\
\hline 2 & $\begin{array}{l}\text { Tuktoyaktuk Coastlands } \\
\text { (multiple sites) }\end{array}$ & $129.25-134.38$ & $69.07-69.83$ & Permafrost & Cryostratigraphy, $\delta^{18} \mathrm{O}, \delta \mathrm{D}$ & $>15 \mathrm{cal}$ & Murton et al. $(2004,2005)$ \\
\hline 3 & $\begin{array}{l}\text { Tuktoyaktuk Coastlands } \\
\text { (multiple sites) }\end{array}$ & $130.09-134.07$ & $69.59-69.86$ & Permafrost & Stratigraphy, geochronology & $\sim 60(\mathrm{OSL})$ & Bateman and Murton (2006) \\
\hline 4 & Bluffers Pingo & 131.89 & 69.74 & Permafrost & Plant macrofossils, pollen & $10.9 \mathrm{cal}$ & Spear (1993) \\
\hline 5 & Reindeer Lake & 132.32 & 69.17 & Lake sediment & Pollen & $17.6 \mathrm{cal}$ & Spear (1993) \\
\hline 6 & Kukjuk Peatland & 132.67 & 69.49 & Permafrost & Pollen, plant macrofossils, $\delta^{18} \mathrm{O}$ & $8.1 \mathrm{cal}$ & Vardy et al. (1997) \\
\hline 7 & $\begin{array}{l}\text { Tuktoyaktuk Coastlands } \\
\text { (multiple sites) }\end{array}$ & $132.76-135.66$ & $69.07-69.68$ & Permafrost & $\delta^{18} \mathrm{O}, \delta \mathrm{D}$ & n.a. & Mackay (1983) \\
\hline 8 & $\begin{array}{l}\text { Tuktoyaktuk Coastlands } \\
\text { (multiple sites) }\end{array}$ & $133.04-135.66$ & $69.40-49.60$ & Permafrost & Geochronology, cryostratigraphy & $\sim 9 \mathrm{cal}$ & Burn (1997) \\
\hline 9 & Campbell Creek Peatland & 133.25 & 69.28 & Permafrost & Pollen, plant macrofossils, $\delta^{18} \mathrm{O}$ & $10.3 \mathrm{cal}$ & Vardy et al. (1998) \\
\hline 10 & Peninsula Point & 133.37 & 69.39 & Permafrost & $\delta^{18} \mathrm{O}, \delta \mathrm{D}$, hydrochemistry & $\sim 17 \mathrm{cal}$ & Mackay and Dallimore (1992) \\
\hline 11 & Tuktoyaktuk 5 & 133.40 & 69.10 & Lake sediment & Pollen & $15.6 \mathrm{cal}$ & Ritchie and Hare (1971) \\
\hline 12 & Twin Tamarack Lake & 133.42 & 68.30 & Lake sediment & Pollen & $15.9 \mathrm{cal}$ & Ritchie et al. (1983), Spear (1993) \\
\hline 13 & Parsons Lake & 133.75 & 68.75 & Permafrost & Ostracods, mollusks, pollen & $11.5 \mathrm{cal}$ & Delorme et al. (1977) \\
\hline 14 & Sleet Lake & 133.82 & 69.29 & Lake sediment & Pollen & $14.6 \mathrm{cal}$ & Ritchie et al. (1983), Spear (1993) \\
\hline 15 & North Head & 134.44 & 69.72 & Permafrost & Cryostratigraphy & $>15 \mathrm{cal}$ & Murton (2005) \\
\hline 16 & Richards Island & 134.50 & 69.33 & Permafrost & $\begin{array}{l}\text { Lithostratigraphy, } \\
\text { seismostratigraphy }\end{array}$ & $\sim 22(\mathrm{OSL})$ & Murton (2009) \\
\hline 17 & Richardson Mts. & 135.10 & 66.03 & Permafrost & Ostracods, mollusks, pollen & $17.5 \mathrm{cal}$ & Delorme et al. (1977) \\
\hline 18 & Ft. McPherson & 135.23 & 67.27 & Permafrost & Ostracods, mollusks, pollen & $11.5 \mathrm{cal}$ & Delorme et al. (1977) \\
\hline 19 & Lateral Pond & 135.93 & 65.95 & Lake sediment & Pollen & $\sim 19$ cal & Ritchie and Cwynar (1982) \\
\hline 20 & Aklavik Plateau & 137.00 & 68.08 & Permafrost & $\delta^{18} \mathrm{O}, \delta \mathrm{D}$ & $\sim 10 \mathrm{cal}$ & Lacelle et al. (2004) \\
\hline 21 & Sabine Point & 137.74 & 69.07 & Permafrost & Cryostratigraphy & $\sim 17 \mathrm{cal}$ & Harry et al. (1988) \\
\hline 22 & Mackenzie Trough & 137.87 & 69.56 & Marine sediment & Foraminifera & $7.0 \mathrm{cal}$ & Schell et al. (2008) \\
\hline 23 & King Point & 137.98 & 69.10 & Permafrost & Cryostratigraphy & $>10 \mathrm{cal}$ & Harry et al. (1985) \\
\hline 24 & Hanging Lake & 138.38 & 68.38 & Lake sediment & Pollen, chironomids & $33{ }^{14} \mathrm{C}[(17 \mathrm{cal})]$ & Cwynar (1982), [Kurek et al. (2009)] \\
\hline 25 & Herschel Island & 138.85 & 69.57 & Fossil vertebrates & Geochronology & $>53{ }^{14} \mathrm{C}$ & Zazula et al. (2009) \\
\hline 26 & Old Crow area & 140.87 & 67.42 & Permafrost & Mollusks, pollen & $18.1 \mathrm{cal}$ & Lauriol et al. (2002) \\
\hline 27 & Clarence Lagoon & 140.87 & 69.62 & Permafrost & Ostracods, pollen & $12.8 \mathrm{cal}$ & Matthews (1975) \\
\hline 28 & Imnavit Creek & 149.33 & 68.38 & Permafrost & Pollen & $17.7 \mathrm{cal}$ & Eisner (1991) \\
\hline 29 & Itkillik River & 150.87 & 69.57 & Permafrost & Sedimentology, geochronology & $>48{ }^{14} \mathrm{C}$ & Kanevskiy et al. (2011) \\
\hline 30 & Ahaliorak Lake & 151.35 & 68.90 & Lake sediment & Pollen & $>35{ }^{14} \mathrm{C}$ & Eisner and Colinvaux (1990) \\
\hline 31 & Ikpikpuk sand sea & 153.00 & 70.20 & Permafrost & Geochronology & $>36{ }^{14} \mathrm{C}$ & Carter (1981) \\
\hline 32 & Ikpikpuk River & 154.88 & 69.72 & Permafrost & Plant macrofossils, fossil beetles & $10.6 \mathrm{cal}$ & Nelson and Carter (1987) \\
\hline 33 & Barrow & 156.40 & 71.07 & Permafrost & Pollen & $9.0 \mathrm{cal}$ & Eisner et al. (2005) \\
\hline 34 & Barrow & 156.67 & 71.30 & Permafrost & $\delta^{18} \mathrm{O}, \delta \mathrm{D}$, geochronology & $14.5 \mathrm{cal}$ & Meyer et al. (2010) \\
\hline
\end{tabular}

$200 \mathrm{~km}$ from the Mackenzie Delta in the southeast to the YukonAlaska border in the northwest where it becomes the Arctic Coastal Plain of Alaska. In the western Canadian Arctic, the LIS probably reached its maximum extent during the Late Wisconsinan (23 to $18 \mathrm{cal} \mathrm{ka} \mathrm{BP),} \mathrm{when} \mathrm{the} \mathrm{ice} \mathrm{margin} \mathrm{extended} \mathrm{well} \mathrm{offshore} \mathrm{in} \mathrm{the} \mathrm{Mac-}$ kenzie Trough seaward of the $-120 \mathrm{~m}$ isobath (Blasco et al., 1990; Fig. 1). Nevertheless, parts of the YCP escaped Quaternary glaciations entirely (Barendregt and Duk-Rodkin, 2004; Duk-Rodkin et al., 2004). The LIS extended into the study area slightly west of Herschel Island, across what is now the modern Firth River (Mackay, 1959; Rampton, 1982; Fig. 2). According to Hughes (1972), the northwestern limit of glaciation is marked by numerous kame terraces and abandoned meltwater channels near Firth River.

The study site near Komakuk Beach (69³6'12.3"N, $140^{\circ} 30^{\prime} 11.8^{\prime \prime}$ $\mathrm{W}$ ) is located between two alluvial fans in the unglaciated western part of the YCP (site 1, Fig. 2). Here, the coastal bluff is rising 8 to $10 \mathrm{~m}$ above sea level (asl) and faces the Beaufort Sea to the north. A sub-horizontal and well-vegetated mesic polygonal terrain, with cottongrass tussock tundra, characterizes the coastal lowland today. West of Firth River, the relief is low, consisting of fluvial deltas and alluvial fans associated with creeks and streams (e.g. Malcolm River) that incise the British Mountains and flow northwards into the Beaufort Sea (Fig. 2).

Herschel Island $\left(69^{\circ} 36^{\prime} \mathrm{N}, 139^{\circ} 04^{\prime} \mathrm{W}\right)$ is located $3 \mathrm{~km}$ offshore in the southern Beaufort Sea, $\sim 100 \mathrm{~km}$ west of the Mackenzie Delta and $60 \mathrm{~km}$ east of Komakuk Beach (Figs. 1 and 2). The island is part of an ice-thrust moraine produced by the advance of the LIS (Mackay, 1959). Large parts of the Herschel Island coast are dominated by steep cliffs up to $50 \mathrm{~m}$ high. Coastal slopes are subject to intense thermo-erosion, including numerous large retrogressive thaw slumps and active-layer detachment slides (Lantuit and Pollard, 2008). The interior of Herschel Island (up to $185 \mathrm{~m}$ asl) has been subject to permafrost heave and subsidence, melt-out of ice wedges, and formation of thermokarst ponds with local peat accumulation, and thermoerosion valleys. Up to $50 \%$ of the near-surface permafrost volume is made up of ground ice (Mackay, 1971).

Sediments on Herschel Island are classified as preglacial, glacial, and postglacial (Bouchard, 1974). Preglacial deposits include those that have undergone ice-thrust deformation, comprising the most common and intricate stratigraphic units on the island. Although sediments affected by glacial ice-thrust are technically glacial in their genesis, they are considered preglacial here in order to reflect their primary origin, as marine, terrestrial, and mixed sediments (Bouchard, 1974). Glacial deposits include thin veneers of meltout till and erratic boulders scattered throughout the surface up to the highest points of the island with a provenance on mainland Canada (Bouchard, 1974). Postglacial deposits are usually related to the accumulation of peat as well as littoral and alluvial processes.

We studied the headwall exposures of two retrogressive thaw slumps in the southern and southeastern parts of Herschel Island (Fig. 2), where the headwall sediments were completely accessible for sampling and that provided a variety of ground ice features and 


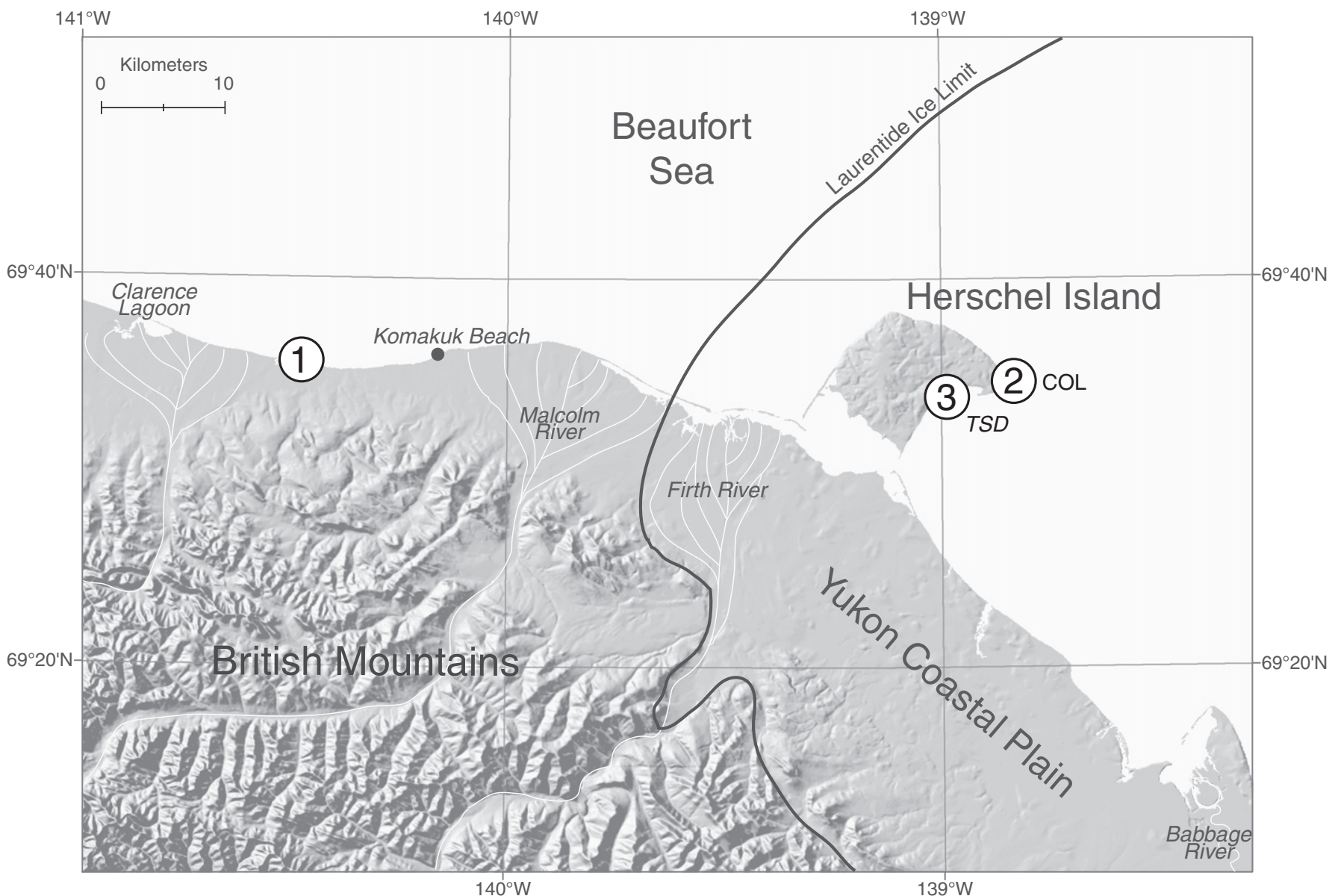

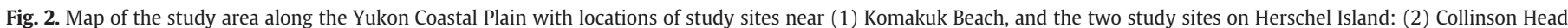
(COL), and (3) thaw slump D (TSD).

sedimentary structures. The one at Collinson Head is henceforth termed COL (site 2, Fig. 2) and the second facing Pauline Cove is termed TSD ("thaw slump D", site 3, Fig. 2).

\section{Material and methods}

Sedimentological and cryolithological characteristics were studied at two exposures at Komakuk Beach and on Herschel Island (Fig. 2). Vertical sediment profiles were sampled at 0.2 to $1.0 \mathrm{~m}$ intervals. This range was determined by the similarity and uniformity of strata and by prominent contacts. Field description of the sediments included color, texture and bedding, organic matter occurrence, and cryostructures. The gravimetric ice content in frozen sediments, expressed as weight percentage (wt.\%), was determined as the mass ratio of ice to dry sample according to van Everdingen (1998). Additionally, ice wedges were sampled using a chain saw, ice screw, or ice axe, depending on the accessibility of the exposures. Samples were thawed in closed plastic bags, then decanted and stored cool in airtight flasks. Electrical conductivity (EC) was measured on thawed ground-ice samples using a WTW Cond340i conductometer in order to assess the total ion content.

A laser particle analyzer (Coulter LS 200) was used for grain-size analyses on freeze-dried and organic-free (treated with $30 \% \mathrm{H}_{2} \mathrm{O}_{2}$ ) subsamples using the $<2 \mathrm{~mm}$ fraction. Total carbon (TC), total organic carbon (TOC), and total nitrogen (TN) contents were measured with a carbon-nitrogen-sulphur (CNS) analyzer (Elementar Vario EL III) and are given as weight percent (wt.\%). The $\mathrm{C} / \mathrm{N}$ ratio is expressed by the quotient of TOC and TN values. Percent carbonate content was calculated as (TC - TOC) $/ 0.12$, where 0.12 is the molar fraction of carbon in $\mathrm{CaCO}_{3}$. Stable carbon isotope ratios $\left(\delta^{13} \mathrm{C}\right)$ of TOC were measured on carbonate-free samples with a Finnigan DELTA $S$ mass spectrometer. The values are expressed in delta per mil notation $(\delta$, $\%$ ) relative to the Vienna Pee Dee Belemnite (VPDB) standard.

Supernatant water from thawed sediments was extracted, and thawed ice-wedge samples were subsampled for stable $\mathrm{O}-\mathrm{H}$ isotope and hydrochemical analyses. The hydrogen and oxygen isotope compositions $\left(\delta \mathrm{D}, \delta^{18} \mathrm{O}\right)$ of ice wedges and segregated ice were determined with a Finnigan MAT Delta-S mass spectrometer, using the equilibration technique (Horita et al., 1989). Values are given as per mil difference from Vienna Standard Mean Ocean Water (VSMOW) standard, with internal $1 \sigma$ errors of better than 0.8 and $0.1 \%$ ofor $\delta D$ and $\delta{ }^{18} \mathrm{O}$, respectively (Meyer et al., 2000). The results are presented in $\delta \mathrm{D}-\delta^{18} \mathrm{O}$ diagrams with respect to the Global Meteoric Water Line (GMWL; $\delta \mathrm{D}=8 \delta^{18} \mathrm{O}+10$; Craig, 1961) and to the modern Local Meteoric Water Line (LMWL) derived from long-term observations in Inuvik $\left(7.3 \delta^{18} \mathrm{O}-3.5 ; \mathrm{R}^{2}=0.98\right.$; IAEA, 2006). In general, the most negative $\delta^{18} \mathrm{O}$ and $\delta \mathrm{D}$ values reflect the coldest temperatures during vapor formation and deposition (Dansgaard, 1964). Second-order parameters such as the linear $\delta \mathrm{D}-\delta^{18} \mathrm{O}$ regression slope and the deuterium excess ( $d$-excess $=\delta D-8 \delta^{18} 0$; Dansgaard, 1964) provide insight into (i) the water source of the initial precipitation, and (ii) the presence or absence of secondary non-equilibrium fractionation processes.

The major cation and anion contents of the water samples from segregated ice were determined by inductively coupled plasmaoptical emission spectrometry (ICP-OES, Perkin-Elmer Optima 3000 $\mathrm{XL}$ ) and ion chromatography (IC, Dionex DX-320), respectively. 

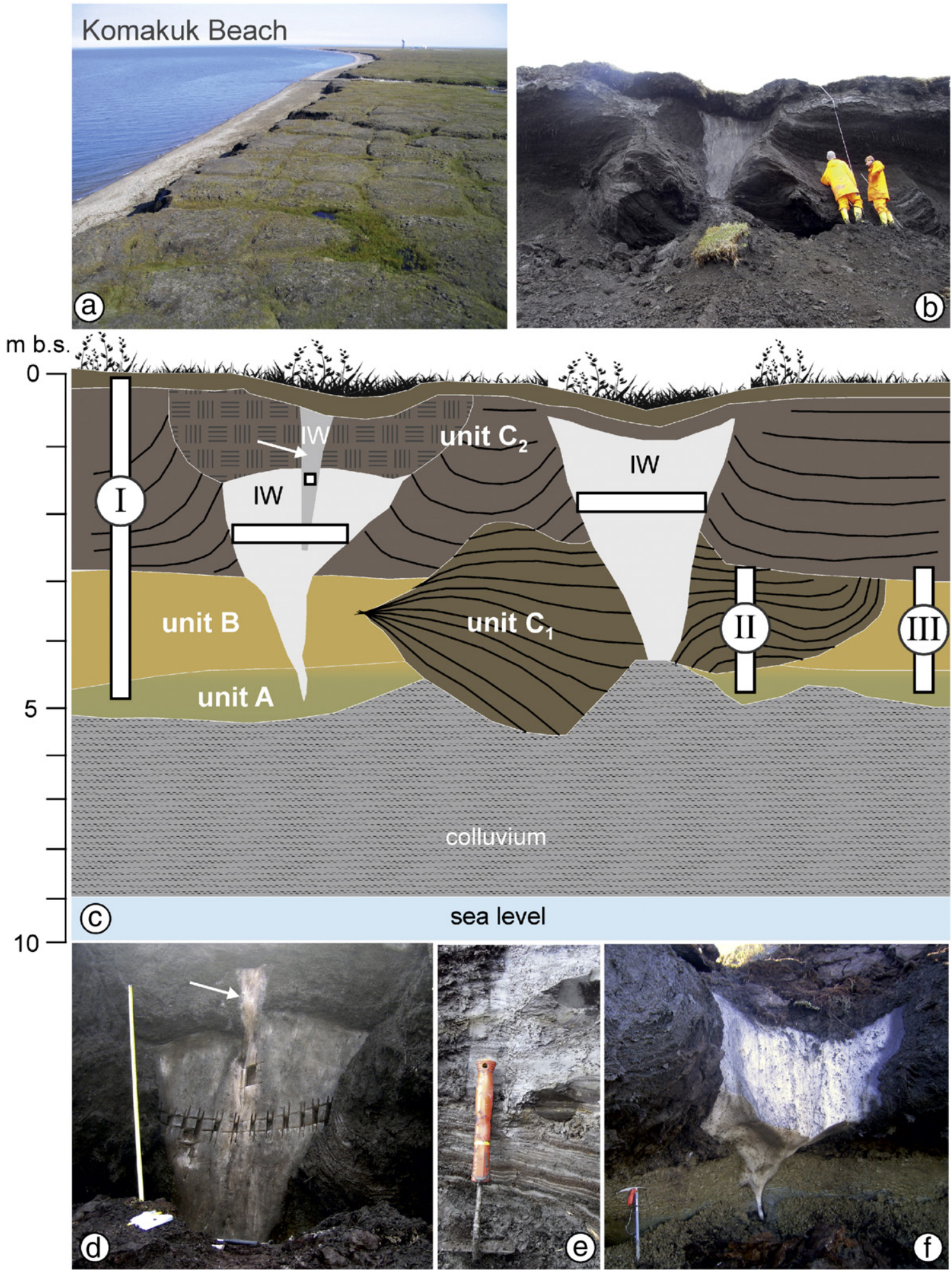

collowium

sea level
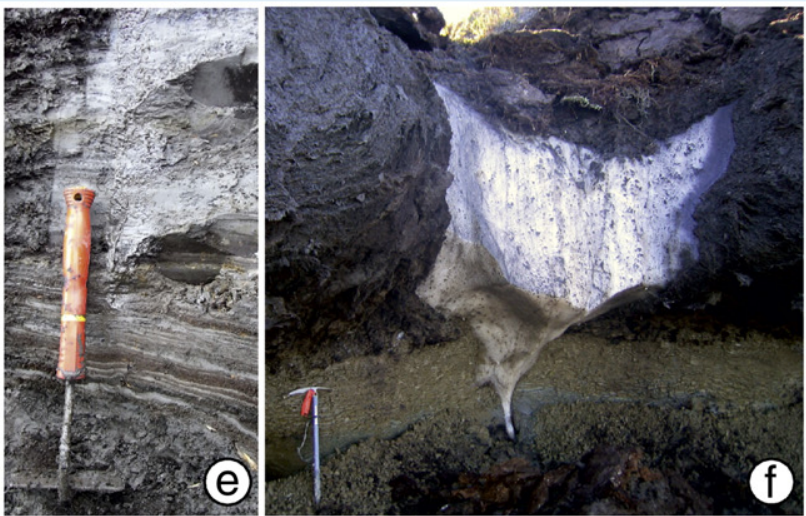

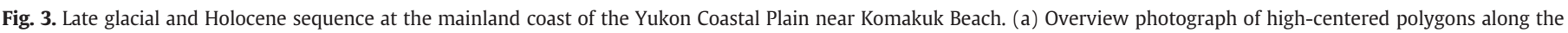

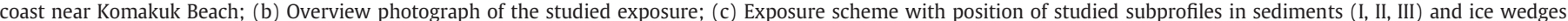

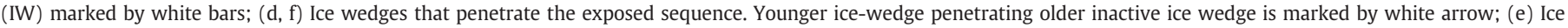
wedge cast (unit $C_{1}$, subprofile II) filled with lacustrine deposits.

Hydrogen carbonate concentrations were measured by titration with $0.01 \mathrm{M} \mathrm{HCl}$ using an automatic titrator (Metrohm 794 Basic Titrino).

Remains of fossil calcareous ostracod shells were retrieved from wet-sieved sediment samples ( $>250 \mu \mathrm{m}$ fraction) within the Komakuk Beach profiles. The ostracod species identification followed North American nomenclature as given by Swain (1963), Delorme
(1968), and Smith and Delorme (2010). Fossil plant fragments were removed from sediment samples under a stereo microscope and multiple fragments were radiocarbon-dated at the Leibniz Laboratory for Radiometric Dating and Stable Isotope Research (Christian Albrechts University, Kiel, Germany) and the Poznan Radiocarbon Laboratory (Adam Mickiewicz University, Poznan, Poland) using accelerator 
mass spectrometry (AMS). Calibrated ages (cal ka BP) were calculated using "CALIB 6.0" (Stuiver and Reimer, 1993; Data set: IntCal09: Reimer et al., 2009) and we chose the 2-sigma range with the highest probability. Radiocarbon dates taken from other studies were recalibrated accordingly.

Additionally, samples for infrared stimulated luminescence (IRSL) dating were acquired using a handheld drilling machine (HILTI TE 5
A) to recover undisturbed horizontal sediment cores from frozen deposits. We used a core chamber equipped with a drill head that holds an opaque plastic cylinder to protect the samples from light. Sample preparation and IRSL analyses were conducted in the luminescence laboratory at the Institute of Geological Sciences, University of Bern, Switzerland (cf. Preusser, 2003). The material used for equivalent dose $\left(D_{e}\right)$ determination was chemically pre-treated using $10 \%$
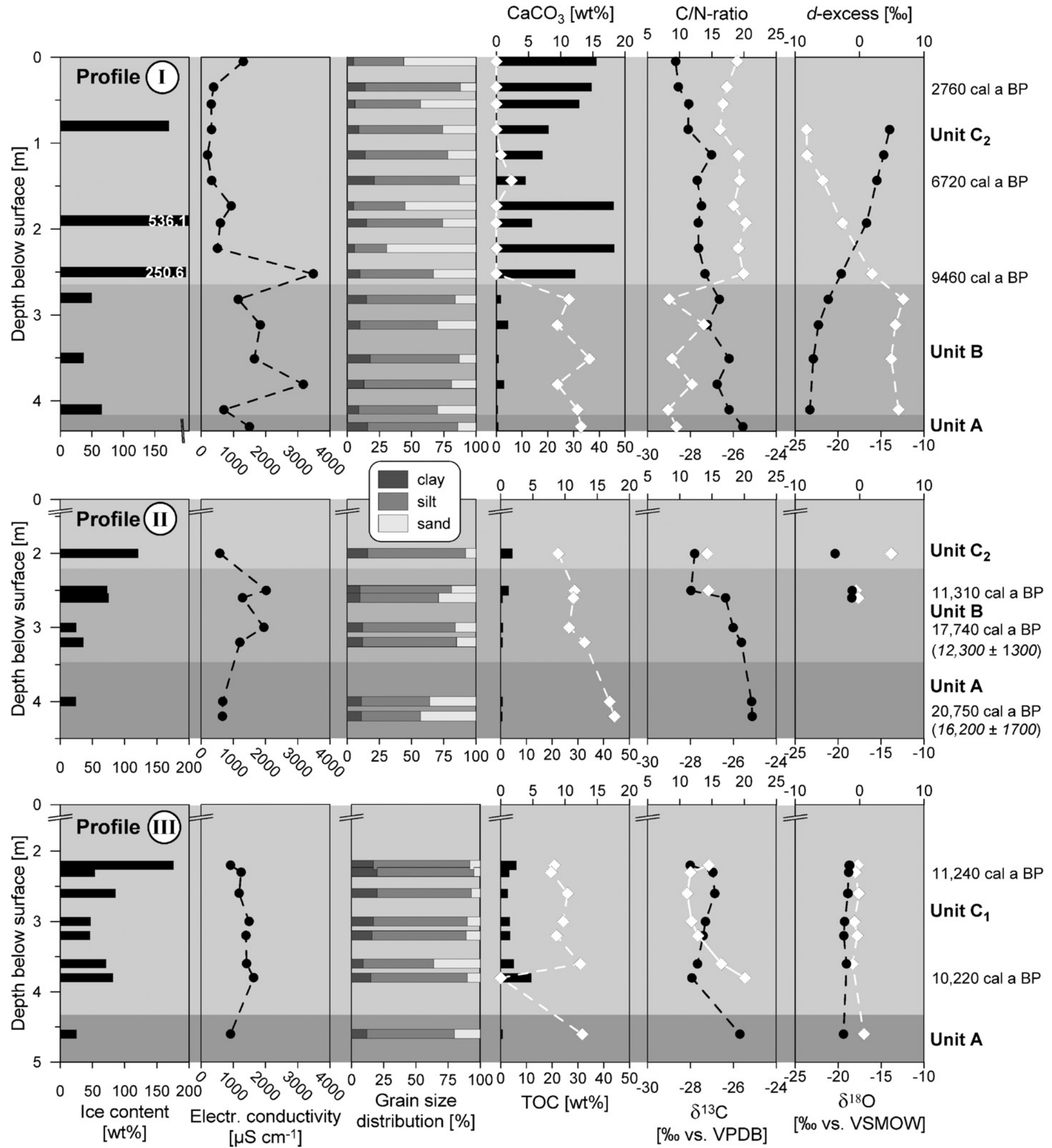

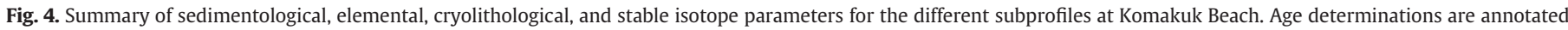

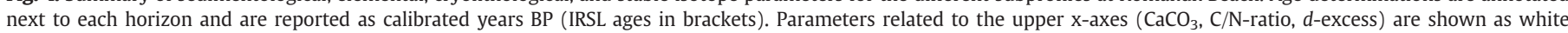
diamonds. 
hydrogen chloride, 30\% hydrogen peroxide, and sodium oxalate. The 4-11 $\mu \mathrm{m}$ fraction was enriched by sedimentation according to Stokes' law. $D_{\mathrm{e}}$ was determined using the modified Single-Aliquots Regenerative (SAR) dose protocol for feldspar using a BG39 and a $410 \mathrm{~nm}$ interference filter. Samples were preheated at $290{ }^{\circ} \mathrm{C}$ for $10 \mathrm{~s}$ prior to all IRSL measurements. Since storage tests identified only a minor signal loss ( $1 \mathrm{~g}$ per decade); no fading correction was carried out. Determination of dose-rate-relevant elements (K, Th, U) was done by highresolution low-level gamma spectrometry (Preusser and Kasper, 2001). The average water content was estimated by using current sediment moisture and adding $10 \%$ uncertainty for the age calculation to account for potential past changes in hydrological conditions.

\section{Results}

\subsection{Litho- and cryostratigraphic properties}

\subsubsection{Komakuk Beach}

Four sediment units $\left(A, B, C_{1}, C_{2}\right)$ were defined according to distinguishing characteristics based on field and laboratory data (Figs. 3 and 4). The lower three meters of the coastal cliff were covered by colluvium and compact snow.

The lowermost, exposed sediments ( 4.0 to $4.5 \mathrm{~m}$ below surface; unit A) are composed of greenish-gray, sandy silt with minor clay content and occasional pebbles up to $1 \mathrm{~cm}$ in diameter (Figs. 4 and 5). Black organic-rich spots and oxidation bands are infrequent. These fine-grained deposits have a massive to parallel fine lens-like cryostructure (ice lenses up to $1 \mathrm{~mm}$ thick) and an ice content of 20 to $25 \mathrm{wt} . \%$. They contain little organic carbon (TOC $<1 \mathrm{wt} . \%$ ) but are rich in $\mathrm{CaCO}_{3}$ (>10 wt.\%) and include rare calcareous ostracod shells and undetermined mollusk remains. $\mathrm{C} / \mathrm{N}$ ratios and $\delta{ }^{13} \mathrm{C}$ values $(\sim 9$ and $-25 \%$ ) are the lowest of the whole sequence (Fig. 4). Plant remains in this unit are sparse and show strong signs of mechanical reworking such as abraded edges and smoothed surfaces.

Unit A was conformably overlain by unit B, comprised of $\sim 1.5 \mathrm{~m}$ of massive yellowish-brown to yellowish-gray silt with minor fine sand and clay (Fig. 3). Sedimentary properties of unit B including bedding, grain size distribution, $\mathrm{CaCO}_{3}$ content, and cryostructures are similar to those of unit A, whereas ice (up to 75 wt.\%) and TOC contents (up to $4.6 \mathrm{wt} . \%$ ) are clearly higher, with TOC increasing to the top of this unit (Figs. 4 and 5). C/N ratios vary between 8 and 14, whereas $\delta^{13} \mathrm{C}$ values $(-28$ to $-26 \%$ ) are slightly depleted compared to those of unit A. Sediment grains were sometimes agglutinated by oxidation crusts. Detrital plant fragments occurred together with wellpreserved seeds and chitin remains. As well, ostracods and mollusk shell fragments were found occasionally.

Unit $\mathrm{C}$ contains an ice-wedge cast up to $7 \mathrm{~m}$ wide and $3 \mathrm{~m}$ thick filling a thermokarst depression (Fig. $3 \mathrm{~b}$ and $\mathrm{c}$ ). The ice-wedge cast deposits contain interbeds of peaty brownish plant detritus and gray fine-sandy silt layers with clay admixtures, from a few millimeters up to several centimeters thick (Figs. 3e and 5). The TOC content ranges from 6 to $12 \%, \mathrm{C} / \mathrm{N}$ ratios decrease upward from 20 to $\sim 11$, whereas $\delta^{13} \mathrm{C}$ values are uniform $(-28$ to $-27 \%$ ). Complete gastropod and ostracod shells are also frequent and point toward a lacustrine origin of these beds. The lowermost horizon underlying the ice-wedge cast contained gray silty deposits similar to the unit A deposits.

Ice-wedge cast deposits of unit $C_{1}$ are conformably overlain by peaty sediments of unit $C_{2}$ (up to $3 \mathrm{~m}$ thick) that comprises the uppermost part of the coastal outcrop (Fig. 3). The contact between both organicrich units is gradual. The basal part of unit $C_{2}$ is composed of layered moss peat overlying unit $B$ apart from the ice-wedge cast (Fig. $3 \mathrm{C}$ and f). The contact between unit $C_{2}$ and $B$ is characterized by oxidation crusts, brown mottles around individual particles, and highlydecomposed organic matter. Further upward in unit $C_{2}$, peat layers with large wood fragments up to $3 \mathrm{~cm}$ in diameter alternate with gray sandy-silt layers 0.2 to $1.0 \mathrm{~cm}$ thick. The uppermost meter of the peat is weakly bedded and contains only occasional particles of fine sand and silt. TOC contents within unit $\mathrm{C}_{2}$ vary between 11 and $46 \%, \mathrm{C} / \mathrm{N}$ ratios are more uniform between 17 and 20, slightly rising in the uppermost meter, whereas $\delta^{13} \mathrm{C}$ values reach their minimum $(-29 \%$ ) toward the surface (Fig. 4). Unit $\mathrm{C}_{2}$ is largely free of carbonate and calcareous fossils, likely due to acidic $\mathrm{pH}$ conditions within the peat. Coarse lens-like cryostructures with ice lenses ( 2 to $5 \mathrm{~cm}$ thick) and high ice contents (120 to $540 \mathrm{wt} . \%$ ) also characterize unit $C_{2}$, reflecting water supersaturation prior to freezing followed by ice segregation at the freezing front during permafrost aggradation.

Ice wedges up to $2.5 \mathrm{~m}$ long and $1.0 \mathrm{~m}$ wide penetrate the whole sedimentary sequence (Fig. 3c, d, and f). They cut through units A and $B$ as epigenetic ice wedges but become broader to the top, where they grew syngenetically with peat accumulation (Fig. 3c, d). These wedges are usually truncated about $1 \mathrm{~m}$ below the surface as the base of an earlier active layer, whereas few ice wedges coincide with the base of the modern active layer. Narrow ice wedges $\sim 25 \mathrm{~cm}$ wide have grown as a younger generation cross-cutting the older ones, and terminate at the base of the modern active layer at 30-40 cm depth (Fig. 3d).

The peaty deposits $\left(C_{2}\right)$ and the underlying units $\left(A, B, C_{1}\right)$ were traced along the coast of the Yukon mainland between Clarence Lagoon and the airstrip at Komakuk Beach during helicopter surveys between 2006 and 2009. We therefore conclude that the sampled locations are representative of a much wider area.

\subsubsection{Herschel Island}

At the TSD site, a tabular massive ice body (unit 1, Fig. 6), $400 \mathrm{~m}$ wide, is present in the headwall of the entire retrogressive thaw slump. Fritz et al. (2011) considered the ice body to be of glacial origin either as buried glacier ice or basal regelation ice. It has an exposed thickness of more than $10 \mathrm{~m}$ and is composed of almost pure ice. The lower contact of the massive ice is not exposed. Sediment inclusions up to pebble-sized clasts are either randomly dispersed or occur as sediment bands with a thickness of $5 \mathrm{~mm}$ to several centimeters. Layers of a matrix-based diamicton are deformed together with the ice, leading to an undulating pattern of anticlinal and synclinal as well as verticallyand horizontally-bedded structures (Fritz et al., 2011).

The massive ice is unconformably overlain by a dark gray to pale gray ice-rich glaciotectonite (unit 2, Fig. 6). This diamicton is composed of clayey, sandy silt with a coarse lens-like reticulate cryostructure and intervening ice lenses ( 2 to $20 \mathrm{~cm}$ thick). Subangular rounded pebbles up to three centimeters in diameter as well as mollusks remains and scattered plant fragments are present throughout unit 2 . The main sediment fraction $(<2 \mathrm{~mm})$ is characterized by a polymictic grain size distribution (Fig. 7). Both units 1 and 2 have

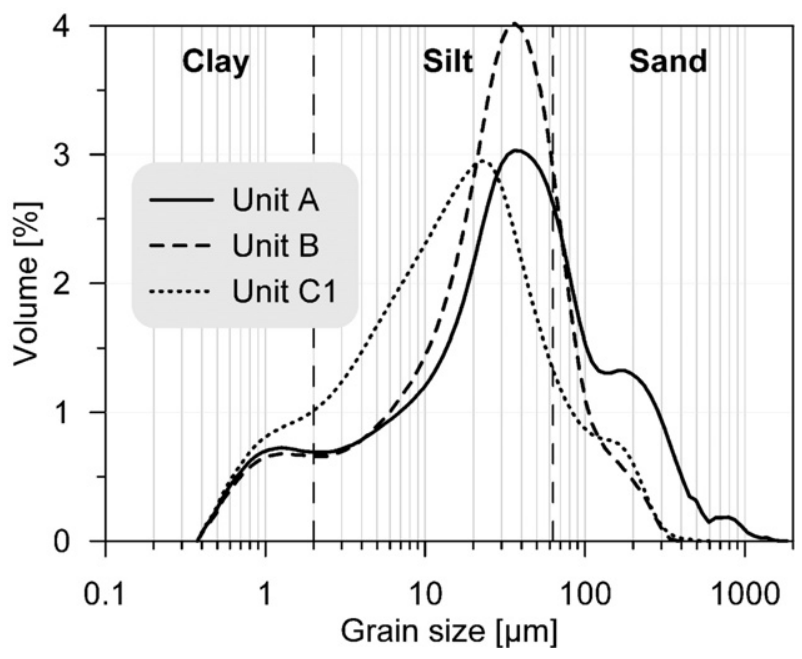

Fig. 5. Average grain-size distribution of units $A, B$, and $C_{1}$ from Komakuk Beach. 

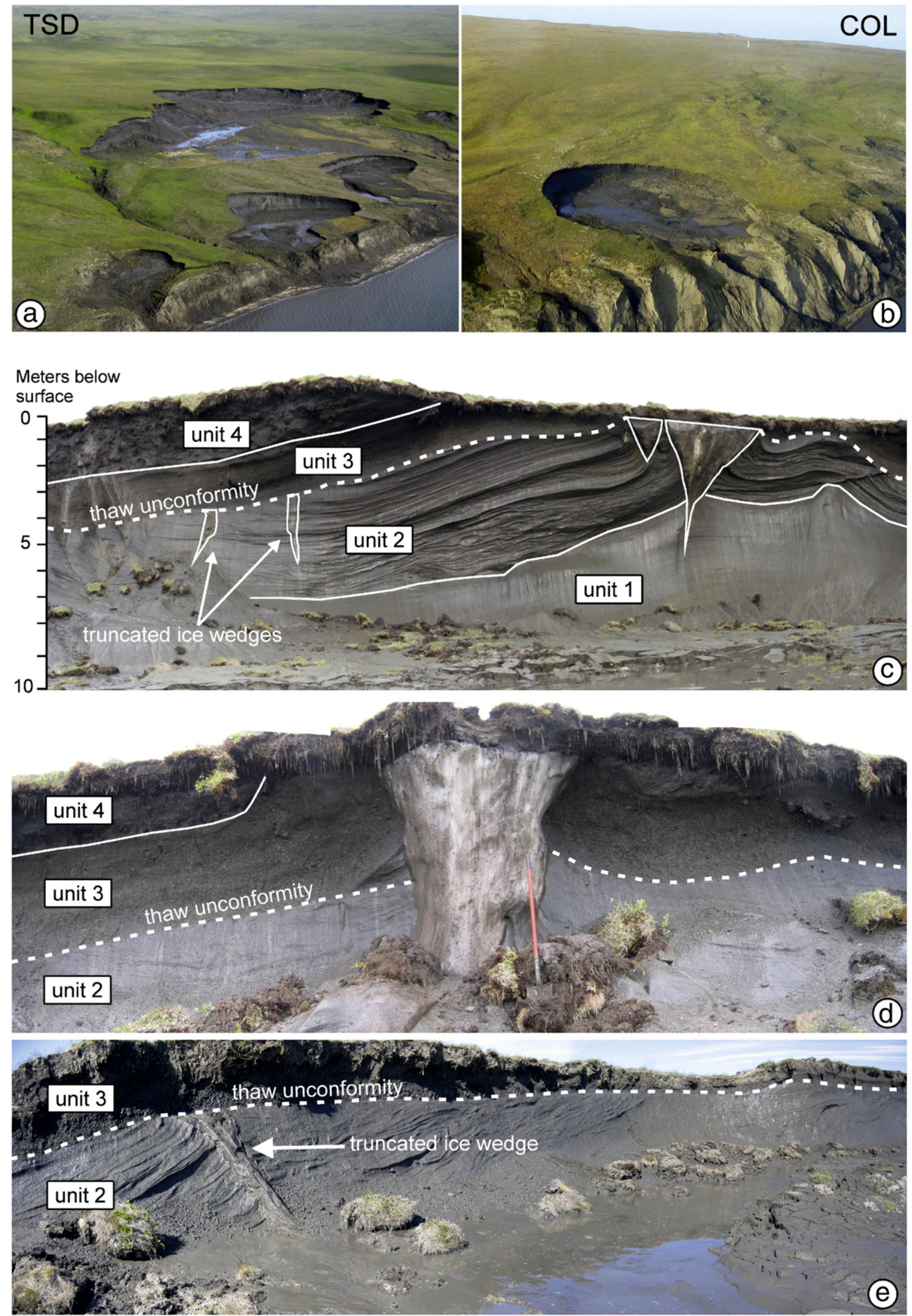

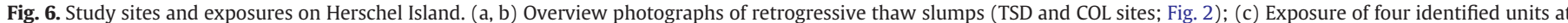

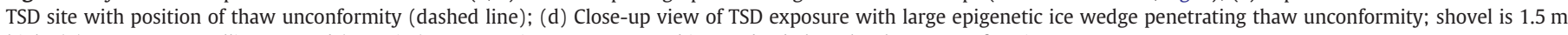
high; (e) Exposure at Collinson Head (COL site). Arrow points to a truncated ice wedge below the thaw unconformity. 

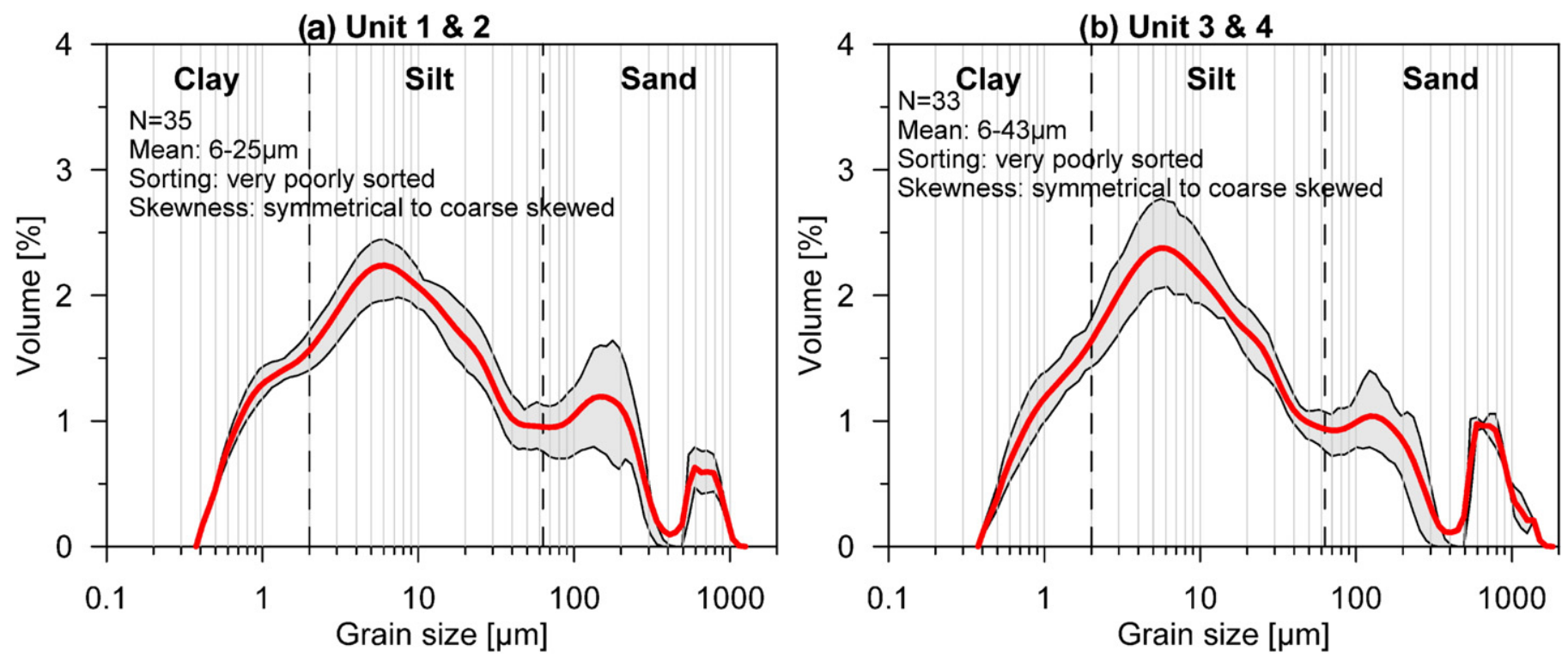

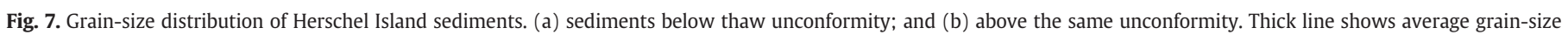
distribution; gray-shaded area covers $25 \%$ and $75 \%$ percentile. Secondary grain-size parameters were calculated according to Inman (1952).

uniformly low TOC (0.6 to $1.6 \mathrm{wt} . \%)$ and TN (0.1 wt.\%) but are rich in $\mathrm{CaCO}_{3}$, averaging $9.2 \mathrm{wt}$ \% (Fig. 8). $\mathrm{C} / \mathrm{N}$ ratios are low with values around 12 , and $\delta^{13} \mathrm{C}$ values plot within a narrow range between -26.6 and $-25.9 \%$. At both sites (TSD and COL), ice-rich sediments (ice content $>50 \mathrm{wt} . \%$ ) up to $5 \mathrm{~m}$ thick exhibited strong deformation, including recumbent folds and boudinage structures. The contact between unit 2 and 3 is discordant as recorded by truncated cryostructures and relict ice wedges that penetrate the diamicton (unit 2) and its deformation structures (Fig. $6 c$ and e). This boundary was visible in the headwalls of both slumps (COL and TSD, Fig. 2) and marks a thaw unconformity corresponding to the maximum depth of a relict active layer (cf. Burn et al., 1986).

Unit 3 is composed of a grayish-brown colluvium up to $3 \mathrm{~m}$ thick (Fig. 6). It contains, on average, less ice than the underlying units (ice content $\geq 30 \mathrm{wt} . \%$ ), and is characterized by a lens-like to irregular reticulate cryostructure. The grain-size distribution of unit 3 is very similar to units 1 and 2 (Fig. 7); however, TOC increases to $17.5 \mathrm{wt} . \%$ around peat inclusions, averaging between 2 and $5 \mathrm{wt} . \%$ (Fig. 8). $\mathrm{CaCO}_{3}$ is usually depleted in unit 3, likely due to leaching by humic acids, and is absent in peaty horizons. $\mathrm{C} / \mathrm{N}$ ratios show a wide range (11 to 23 ), with higher values reflecting less decomposition of organic-rich parts (Fig. 8).

Unit 4 (Fig. 6c and d) occupies former depressions of low-centered ice-wedge polygons recorded by thick peat lenses $(\sim 50 \mathrm{~cm})$ and organic-rich boggy sediments up to $2.5 \mathrm{~m}$ thick conformably overlying the clayey colluvium of unit 3. Inactive ice wedges up to $2.5 \mathrm{~m}$ wide and $5 \mathrm{~m}$ deep penetrate units 2 and 3 and sometimes extend into the massive ice of unit 1 (Fig. 6c).

The very poorly-sorted diamictons (units 2 and 3, Figs. 7 and 8) on Herschel Island are considered to be polygenetic and are interpreted to be of glacially-reworked marine, near-shore marine, and terrestrial origin (Mackay, 1959; Bouchard, 1974). They have been ice-thrust (glaciotectonized) and redeposited by the LIS as it advanced across the exposed shelf of the Beaufort Sea. These deposits have subsequently been altered by periglacial processes (development of ice wedges, active-layer deepening, peat accumulation, etc.).

\subsection{Geochronology}

Twenty-one samples were radiocarbon dated by accelerator mass spectrometry (AMS, Table 2). Nine samples were collected at Komakuk Beach, whereas on Herschel Island, eight samples were collected from site 3 (TSD), and four from site 2 (COL, Fig. 2). Based on these dates, the silt-dominated minerogenic sediments of units A and B (Komakuk Beach) accumulated during the Late Wisconsinan between 20.7 and $11.3 \mathrm{cal}$ ka BP. These radiocarbon dates were supported by parallel IRSL age determinations of two samples from the same units. The obtained IRSL ages of $16.2 \pm 1.7$ and $12.3 \pm 1.3 \mathrm{ka}$ (Table 3 ) are consistent with the corresponding radiocarbon ages, although the IRSL ages are slightly younger for samples at similar depth. An age of $48.4 \mathrm{ka}$ BP obtained from unit A is not taken into account for the stratigraphic interpretation because the dated material includes redeposited (autochthonous) woody fragments that may include a mixture of ages. The bedded peaty deposits of unit $\mathrm{C}_{2}$ yield Holocene ages ( 9.5 and $2.8 \mathrm{cal} \mathrm{ka} \mathrm{BP}$ ) and the ice wedge cast deposits of unit $C_{1}$ dated to 11.2 and $10.2 \mathrm{cal} \mathrm{ka} B$. Two samples from units $A$ and $\mathrm{B}$ provided midpoint ages of 20.7 and $17.7 \mathrm{cal} \mathrm{ka} \mathrm{BP}$ (Table 2). These represent rare radiocarbon dates on organic remains of fullglacial age in easternmost Beringia immediately distal to the alltime limit of the northwest LIS.

The ages of Herschel Island sediments vary widely, from non-finite to modern (post-bomb) and include age inversions within each unit. Dates below the thaw unconformity separating units 2 and 3 (Fig. 6) are as young as $16.2 \mathrm{cal} \mathrm{ka} \mathrm{BP;} \mathrm{however,} \mathrm{most} \mathrm{samples} \mathrm{are} \mathrm{near} \mathrm{the}$ radiocarbon determination limit or of non-finite age. Unit 3 deposits above the cryostratigraphic unconformity yield ages younger than $\sim 12$ cal ka BP except for one older date of 32.0 cal ka BP directly above the transition from unit 2 to 3 ( $1.8 \mathrm{~m}$ below surface). This suggests that the thaw unconformity formed at about 12 cal ka BP when summer insolation approached its maximum (Kaufman et al., 2004).

Additionally, two samples for IRSL dating were taken below the COL site (Fig. 2) from bedded sandy deposits with gravel bands and marine mollusk remains, stratigraphically underlying oxidized gravel beds with mollusk remains about $40 \mathrm{~m}$ asl. Regarded as preglacial, near-shore facies sediments (Bouchard, 1974), they gave IRSL ages of $87 \pm 11 \mathrm{ka}$ and $74 \pm 8 \mathrm{ka}$ (Table 3 ), reinforcing this interpretation.

\subsection{Ground ice}

4.3.1. Stable water isotopes of tabular massive ice, ice wedges, and segregated ice

Table 4 summarizes the results for the different locations and ice types. The stable $\mathrm{O}-\mathrm{H}$ isotope composition from tabular massive 


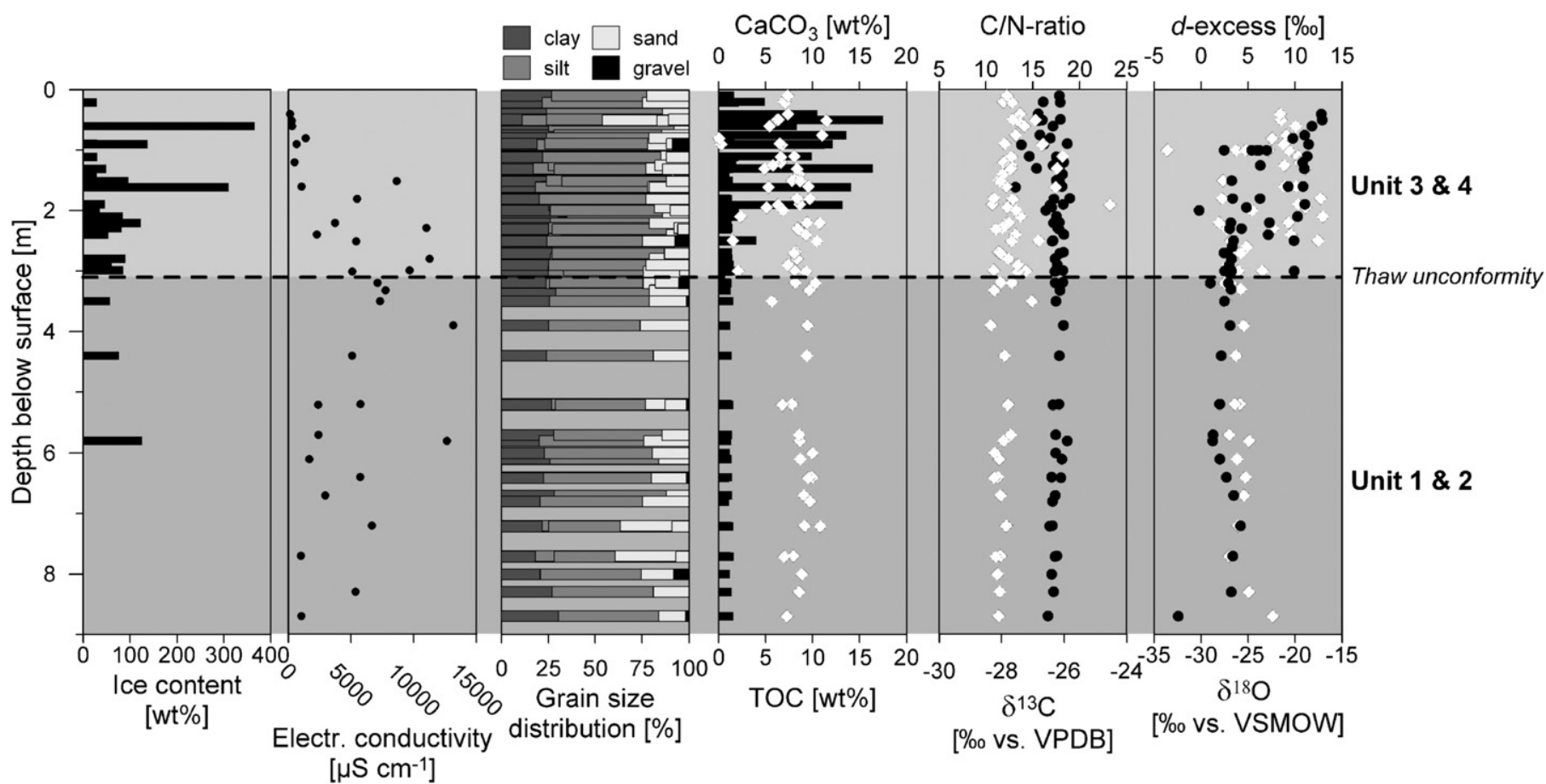

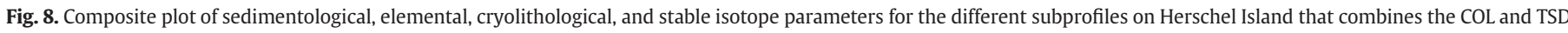
sites. Parameters related to the upper x-axes $\left(\mathrm{CaCO}_{3}, \mathrm{C} / \mathrm{N}\right.$-ratio, $d$-excess $)$ are shown as white diamonds. Dashed line delineates lowermost position of the thaw unconformity.

ground ice (unit 1, TSD, Herschel Island, Fig. 6) was previously described in detail by Fritz et al. (2011). These samples gave the lowest $\delta^{18} \mathrm{O}$ values of all studied ice types, ranging from -34.2 to $-31.3 \%$ 。 (Table 4). With a $\delta \mathrm{D}-\delta^{18} \mathrm{O}$ regression slope value of $7.0\left(\mathrm{R}^{2}=0.98\right)$ and an average $d$-excess of $7.2 \%$, the massive ice samples lie slightly below the GMWL.

Ice wedges at Komakuk Beach and on Herschel Island can be differentiated into two major groups based on their O-H isotope composition and stratigraphic relationships (Table 4). $\delta^{18} \mathrm{O}$ values from ice wedges at Komakuk Beach range between -24.8 and $-20.5 \%$
(Fig. 9a). The mean $d$-excess of $7.1 \%$ and $\delta \mathrm{D}-\delta^{18} \mathrm{O}$ regression slope of $7.1\left(R^{2}=0.99\right)$ indicate that these samples lie slightly below the GMWL. Ice wedges from Herschel Island plot in a similar range for $\delta^{18} \mathrm{O}(-25.6$ to $-19.4 \%$ ) and $d$-excess (mean: $9.7 \%$ ), and along a regression slope of $7.7\left(R^{2}=0.99\right)$ which is close to the GMWL (Fig. 9a).

A small number of truncated ice-wedge roots were encountered below the distinct thaw unconformity, 1.5 to $3.0 \mathrm{~m}$ below the surface on Herschel Island (Fig. $6 \mathrm{c}$ and e). Similar deeply-truncated ice wedges were not found at Komakuk Beach. Truncated, brownish sediment-bearing ice wedges from Herschel Island exhibited low

Table 2

Summary of AMS ${ }^{14} \mathrm{C}$ results. HI: Herschel Island, KOM: Komakuk Beach, LW: Late Wisconsinan, EH: early Holocene, MH: middle Holocene, LH: late Holocene.

\begin{tabular}{|c|c|c|c|c|c|c|c|c|}
\hline Location & Unit & $\begin{array}{l}\text { Depth below surface } \\
{[\mathrm{m}]}\end{array}$ & Dated material & $\begin{array}{l}\text { Uncalibrated }{ }^{14} \mathrm{C} \text { ages } \\
\text { [years BP] }\end{array}$ & $\begin{array}{l}\text { Calibrated age range } \\
\text { [cal years BP], } 2 \sigma\end{array}$ & $\begin{array}{l}\text { Midpoint } 2 \sigma \text {-age } \\
\text { [cal years BP] }\end{array}$ & Lab no. ${ }^{\mathrm{a}}$ & $\begin{array}{l}\text { Stratigraphical } \\
\text { assignment }\end{array}$ \\
\hline KOM & $\mathrm{C}_{2}$ & 0.3 & Peat, in situ & $2637 \pm 31$ & $2792-2725$ & 2759 & KIA32230 & $\mathrm{LH}$ \\
\hline КОМ & $\mathrm{C}_{2}$ & 1.4 & Peat, in situ & $5890 \pm 40$ & $6798-6634$ & 6716 & Poz-36431 & $\mathrm{EH} / \mathrm{MH}$ \\
\hline KOM & $\mathrm{C}_{2}$ & 2.5 & Peat, in situ & $8405 \pm 45$ & 9522-9394 & 9458 & KIA32229 & $\mathrm{EH}$ \\
\hline KOM & $\mathrm{B} / \mathrm{C}_{2}$ & 2.5 & Rootlets, in situ & $9890 \pm 50$ & $11,407-11,203$ & 11,305 & Poz-36432 & LW/EH \\
\hline KOM & $\mathrm{C}_{1}$ & 2.3 & Peat, in situ & $9810 \pm 60$ & $11,355-11,124$ & 11,240 & Poz-36436 & $\mathrm{EH}$ \\
\hline KOM & $\mathrm{C}_{1}$ & 3.8 & Peat, in situ & $9050 \pm 50$ & $10,297-10,151$ & 10,224 & Poz-36437 & $\mathrm{EH}$ \\
\hline KOM & $\mathrm{B}$ & 3.0 & Vascular plant detritus & $14,620 \pm 80$ & $18,056-17,413$ & 17,735 & Poz-36433 & LW \\
\hline KOM & A & 4.2 & Vascular plant detritus & $17,370 \pm 100$ & $21,184-20,309$ & 20,747 & Poz-36435 & LW \\
\hline KOM & A & 4.3 & Wood fragment, allochthonous & $48,400+3270 /-2320$ & - & - & KIA32228 & b \\
\hline $\mathrm{HI}$ & 3 & 0.8 & Vascular plant detritus & $9840 \pm 60$ & $11,400-11,161$ & 11,281 & Poz-36438 & Above unconformity \\
\hline $\mathrm{HI}$ & 3 & 0.9 & Vascular plant detritus & $1110 \pm 35$ & 1084-933 & 1009 & KIA32232 & Above unconformity \\
\hline HI & 3 & 0.8 & Vascular plant detritus & $2290 \pm 30$ & $2353-2030$ & 2192 & KIA32236 & Above unconformity \\
\hline HI & 3 & 1.1 & Vascular plant detritus & $625 \pm 35$ & $661-550$ & 606 & KIA32234 & Above unconformity \\
\hline HI & 3 & 1.8 & Vascular plant detritus & $27,660 \pm 350$ & $32,811-31,264$ & 32,038 & Poz-36430 & Above unconformity \\
\hline HI & 3 & 2.0 & Vascular plant detritus & $8660 \pm 50$ & $9744-9532$ & 9638 & Poz-36439 & Above unconformity \\
\hline $\mathrm{HI}$ & 3 & 2.3 & Vascular plant detritus & > 1954 A.D. & - & - & KIA32233 & Above unconformity \\
\hline HI & 3 & 3.0 & Vascular plant detritus & $10,190 \pm 50$ & $12,076-11,704$ & 11,890 & KIA32235 & Above unconformity \\
\hline HI & 2 & 3.2 & Vascular plant detritus & $>48,000$ & - & - & Poz-36429 & Below unconformity \\
\hline HI & 2 & 3.5 & Vascular plant detritus & $50,770+3800 /-2570$ & - & - & KIA32231 & Below unconformity \\
\hline $\mathrm{HI}$ & 2 & 6.1 & Vascular plant detritus & $37,400 \pm 1000$ & $43,751-40,419$ & 42,085 & Poz-36440 & Below unconformity \\
\hline HI & 2 & 7.7 & Vascular plant detritus & $13,300 \pm 70$ & $16,781-15,609$ & 16,195 & Poz-36441 & Below unconformity \\
\hline
\end{tabular}

a $\mathrm{KIA}=$ Christian Albrechts University Kiel. Poz = Poznan Radiocarbon Laboratory.

b Not used for interpretation for reasons see in the text.

c From Lantuit et al. (under review). 
Table 3

Summary of IRSL dating results. HI: Herschel Island, KOM: Komakuk Beach, $\mathrm{D}_{\mathrm{e}}$ : equivalent dose, $\mathrm{D}_{\text {rate }}$ : dose rate.

\begin{tabular}{|c|c|c|c|c|c|c|c|}
\hline Location & Lab no. & $\begin{array}{l}\text { Depth below surface } \\
{[\mathrm{m}]}\end{array}$ & Description of sediment & $\begin{array}{l}\text { Facies } \\
\text { interpretation }\end{array}$ & $\begin{array}{l}D_{e} \\
{[G y]}\end{array}$ & $\begin{array}{l}\text { D rate } \\
{[\mathrm{Gy} / \mathrm{ka}]}\end{array}$ & $\begin{array}{l}\text { IRSL age } \\
{[\mathrm{ka}]}\end{array}$ \\
\hline KOM & KOM1 & 3.0 & $\begin{array}{l}\text { See unit B, massive silt with fine sand and clay, TOC up to } 4.6 \% \text {, detrital } \\
\text { plant fragments, massive cryostructure }\end{array}$ & $\begin{array}{l}\text { Alluvial-proluvial } \\
\text { plain with loess }\end{array}$ & $33.4 \pm 0.7$ & $2.72 \pm 0.28$ & $12.3 \pm 1.3$ \\
\hline KOM & KOM2 & 4.0 & $\begin{array}{l}\text { See unit A, massive sandy silt with clay, occasional pebbles, TOC: }<1 \% \text {, } \\
\text { very few detrital plant fragments, massive cryostructure }\end{array}$ & Alluvial plain & $45.2 \pm 1.4$ & $2.79 \pm 0.28$ & $16.2 \pm 1.7$ \\
\hline $\mathrm{HI}$ & COL2 & 1.5 & Bedded sand with gravel bands, shell fragments, unfrozen & $\begin{array}{l}\text { Pre-glacial beach } \\
\text { deposits }\end{array}$ & $239.2 \pm 14.6$ & $2.75 \pm 0.30$ & $87 \pm 11$ \\
\hline $\mathrm{HI}$ & COL1 & 1.9 & Bedded sand with gravel bands, shell fragments, unfrozen & $\begin{array}{l}\text { Pre-glacial beach } \\
\text { deposits }\end{array}$ & $205.2 \pm 7.9$ & $2.77 \pm 0.28$ & $74 \pm 8$ \\
\hline
\end{tabular}

mean $\delta{ }^{18} \mathrm{O}$ values of $-29.1 \%$ (Fig. 9a) and a low mean $d$-excess of $0.1 \%$, and therefore plot beneath the GMWL along a regression slope value of $7.8\left(R^{2}=0.99\right)$.

Preservation of pore water during formation of segregated ice occurs via a wide range of processes. Nevertheless, Mackay (1983), Murton and French (1994), Kotler and Burn (2000), and Schwamborn et al. (2006) have shown that stable O-H isotopes in segregated ice can still reflect environmental and climatic changes when considered with caution. Peat deposits at Komakuk Beach show relatively high $\delta^{18} \mathrm{O}$ values between -19.6 and $-14.0 \%$ and low $d$-excess values between -8.2 and $1.9 \%$. Lower $\delta^{18} \mathrm{O}$ values are accompanied by higher values for $d$-excess and vice versa (Figs. 4 and $9 \mathrm{~b}$ ). Pore ice within the fine-grained sediments of units $A$ and $B$ has $\delta^{18} O$ values of $-22.2 \pm 1.1 \%$ and an average $d$-excess of $5.9 \pm 0.9 \%$. The stable $\mathrm{O}-\mathrm{H}$ isotope composition of Herschel Island segregated ice mirrors the general cryostratigraphy of two zones. At the COL and TSD sites, $\delta^{18} \mathrm{O}$ values beneath the thaw unconformity average below $-26 \%$, with a minimum of $-30.8 \%$ and an average $d$-excess of $2.8 \%$. In contrast, a large range in $\delta^{18} \mathrm{O}(-25.2$ to $-17.1 \%)$ and $d$-excess (1.6 to $12.9 \%$ ) occur in deposits above the unconformity (Fig. $9 \mathrm{~b}$ ).

\subsubsection{Hydrochemistry of segregated ice}

The major ion composition of segregated ice along Komakuk Beach can be subdivided according to the described stratigraphic units (Table 5). Unit A (lowermost) has an EC between 5000 and $7000 \mu \mathrm{S} / \mathrm{cm}$ and is dominated by $\mathrm{Na}^{+}$(52\%) and $\mathrm{Cl}^{-}$(67\%), with second-order proportions of $\mathrm{Ca}^{2+}, \mathrm{Mg}^{2+}$, and $\mathrm{SO}_{4}^{2-}$, whereas $\mathrm{HCO}_{3}^{-}$ is sparse. The pore water hydrochemistry of unit $\mathrm{B}$ is highly variable, with EC values ranging between 2700 and $17,800 \mu \mathrm{S} / \mathrm{cm}$. This unit shows high loads of $\mathrm{Ca}^{2+}(48 \%)$ and $\mathrm{SO}_{4}^{2}(40 \%)$; whereas $\mathrm{HCO}_{3}^{-}$is again sparse. Samples in which EC is highest are enriched in $\mathrm{Na}^{+}$ and $\mathrm{Cl}^{-}$ions and depleted in $\mathrm{Ca}^{2+}$ and $\mathrm{SO}_{4}^{2-}$. Segregated ice from ice-wedge casts of unit $C_{1}$ shows average proportions of $51 \%$ and $32 \%$ for the dominant cations $\left(\mathrm{Ca}^{2+}\right.$ and $\left.\mathrm{Mg}^{2+}\right)$; whereas anion proportions are highly variable, i.e. $\mathrm{SO}_{4}^{2-}$ (10 to $70 \%$ ), $\mathrm{HCO}_{3}^{-}$(3 to $42 \%$ ), and $\mathrm{Cl}^{-}$(16 to $76 \%$ ). EC values of Unit $\mathrm{C}_{2}$ are generally lower than $800 \mu \mathrm{S} / \mathrm{cm}$ and are dominated by $\mathrm{Ca}^{2+}(69 \%)$ and $\mathrm{HCO}_{3}^{-}(76 \%)$; whereas $\mathrm{SO}_{4}^{2-}$ is rare. One exception is the lowermost peat horizon $(\mathrm{EC}=5200 \mu \mathrm{S} / \mathrm{cm})$ just above the minerogenic unit B. Here, $\mathrm{Cl}^{-}$and $\mathrm{SO}_{4}^{2-}$ ions are enriched, $\mathrm{HCO}_{3}^{-}$is absent, whereas manganese $\left(\mathrm{Mn}^{2+}\right.$ : $11.0 \mathrm{mg} / \mathrm{l}$ ) and nitrate ions $\left(\mathrm{NO}_{3}^{-}: 113.5 \mathrm{mg} / \mathrm{l}\right.$ ) are notable. Values above the thaw unconformity show a larger variability and higher concentrations of $\mathrm{Mg}^{2+}, \mathrm{Ca}^{2+}$, and $\mathrm{HCO}_{3}^{-}$.

The major ion composition of segregated ice derived from Herschel Island reflects the marine origin of host sediments (Fritz et al., 2011 ) with a generally high EC up to $14,000 \mu \mathrm{S} / \mathrm{cm}$ and a dominance of $\mathrm{Na}^{+}$and $\mathrm{Cl}^{-}$ions (Table 5).

\subsection{Ostracod studies at Komakuk Beach}

Eight ostracod taxa were identified to species level, one to genus level, and one taxon to its subfamily level (Table 6). All identified taxa belong to freshwater habitats. Unit A sediments (Fig. 3) contain few specimens of juvenile Cypria exsculpta and juvenile Candoninae. The latter are also present throughout unit B sediments, although rarely. The highest ostracod occurrence and diversity was observed within unit $B$ at the contact with the overlying peat of unit $C_{2}$. In this zone the assemblage comprises nine taxa including the species Ilyocypris biplicata, C. exsculpta, Limnocythere camera, Limnocytherina sanctipatricii, Candona candida, C. rectangulata and Fabaeformiscandona caudata. No other peat samples contained ostracod remains. Ephippia (resting eggs) of Daphnia sp. and mollusk shell fragments were also found in unit B. The ice wedge cast (unit $C_{1}$ ) contained Cytherissa lacustris, C. candida, C. exsculpta, I. biplicata, and juvenile Candoninae, along with mollusk shells and freshwater plant macrofossils (Potamogeton sp. and Hippuris sp.). The exclusive occurrence of freshwater species in all sediment beds at Komakuk Beach provide

Table 4

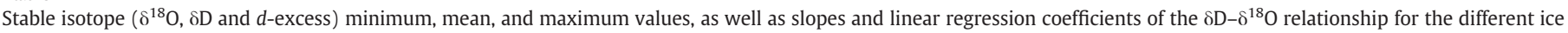
types sampled. HI: Herschel Island, KOM: Komakuk Beach.

\begin{tabular}{|c|c|c|c|c|c|c|c|c|c|c|c|c|c|c|}
\hline \multirow[t]{2}{*}{ Location } & \multirow[t]{2}{*}{ Ice type } & \multirow[t]{2}{*}{$\mathrm{N}$} & \multicolumn{3}{|c|}{$\begin{array}{l}\delta^{18} \mathrm{O} \\
{[\% \circ]}\end{array}$} & \multicolumn{3}{|c|}{$\begin{array}{c}\delta \mathrm{D} \\
{[\%]}\end{array}$} & \multicolumn{3}{|c|}{$\begin{array}{c}d \text {-excess } \\
{[\% \circ]}\end{array}$} & \multirow[t]{2}{*}{ Slope } & \multirow[t]{2}{*}{$\mathrm{R}^{2}$} & \multirow[t]{2}{*}{ Stratigraphic affiliation } \\
\hline & & & Min. & Mean & Max. & Min. & Mean & Max. & Min. & Mean & Max. & & & \\
\hline KOM & Ice wedge & 25 & -24.8 & -23.3 & -20.5 & -189 & -179 & -159 & 5.1 & 7.2 & 9.2 & 7.1 & 0.99 & Holocene \\
\hline $\mathrm{HI}$ & Ice wedge & 105 & -25.6 & -22.1 & -19.4 & -200 & -167 & -146 & 4.4 & 9.7 & 12.6 & 7.7 & 0.99 & $\begin{array}{l}\text { Above unconformity (unit } 3 \text { and } 4 \text { ); } \\
\text { Holocene }\end{array}$ \\
\hline HI & Ice wedge & 18 & -30.7 & -29.1 & -26.5 & -245 & -232 & -213 & -2.8 & 0.1 & 1.7 & 7.8 & 0.99 & $\begin{array}{l}\text { Below unconformity (unit 2); Late } \\
\text { Wisconsinan }\end{array}$ \\
\hline KOM & Segregated ice & 21 & -23.3 & -19.0 & -14.0 & -180 & -152 & -120 & -8.2 & 0.1 & 6.8 & 6.3 & 0.99 & Late Wisconsinan to sub-recent \\
\hline HI & Segregated ice & 21 & -25.2 & -20.3 & -17.1 & -190 & -153 & -129 & 1.6 & 9.5 & 12.9 & 8.0 & 0.98 & $\begin{array}{l}\text { Above unconformity (unit } 3 \text { and } 4 \text { ); } \\
\text { Holocene }\end{array}$ \\
\hline HI & Segregated ice ${ }^{a}$ & 44 & -30.8 & -27.8 & -25.7 & -243 & -219 & -198 & -1.3 & 2.8 & 7.7 & 8.8 & 0.97 & $\begin{array}{l}\text { Below unconformity (unit 2); Late } \\
\text { Wisconsinan }\end{array}$ \\
\hline HI & Tabular massive ground ice ${ }^{a}$ & 40 & -34.2 & -33.0 & -31.3 & -265 & -258 & -244 & 5.3 & 7.2 & 9.3 & 7.0 & 0.98 & Late Wisconsinan (unit 1); \\
\hline
\end{tabular}

\footnotetext{
a Includes data from Fritz et al. (2011).
} 

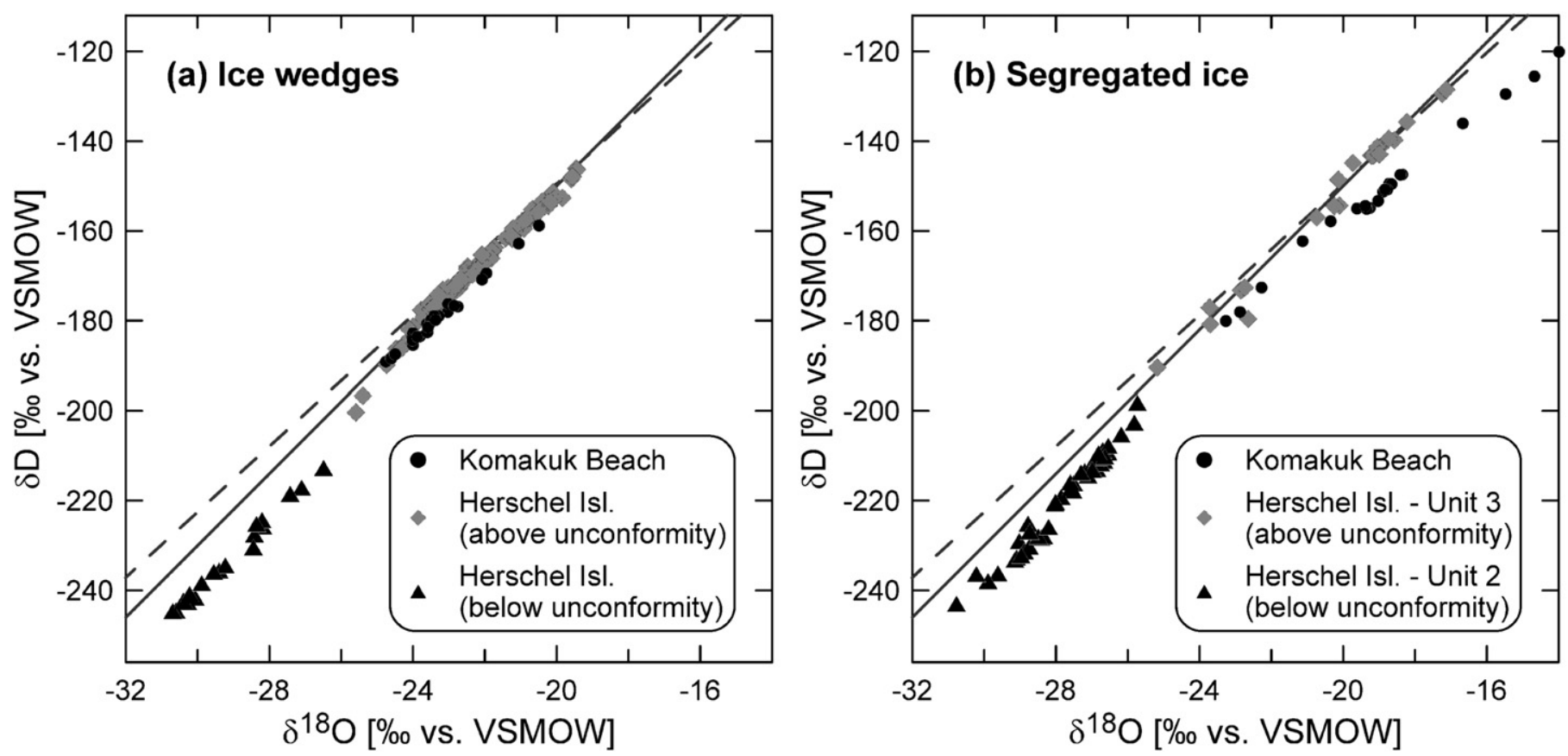

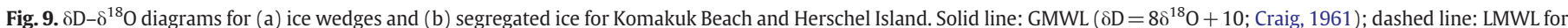
Inuvik $\left(\delta D=7.3 \delta^{18} \mathrm{O}-3.5 ; \mathrm{R}^{2}=0.98\right.$; IAEA, 2006).

valuable information that all units formed under non-marine but terrestrial conditions.

\section{Discussion}

\subsection{Late Wisconsinan landscape evolution}

\subsubsection{Glacial chronology}

Several attempts have been made to determine the formation age of Herschel Island as ice-thrust moraine and the respective timing of the maximum LIS extent along the YCP. Establishing this chronology is confounded by the stratigraphy on Herschel Island, which is the product of glaciotectonism (Mackay, 1959; Bouchard, 1974). The youngest date of 16.2 cal ka BP obtained from the glaciotectonite of unit 2 presumably provides a maximum age for its deposition. The sediments of unit 2 were post-depositionally glaciotectonized, and the dated plant material that it contains accumulated prior to the deformation. Therefore, the advance of the northwest LIS to its maximum extent, and the formation of Herschel Island itself, might be as young as $16.2 \mathrm{cal}$ ka BP. A previous indication of its formation age is based on a single date of a Yukon horse skull (Equus lambei) with an age range of 19.6 to 18.9 cal ka BP (Harington, 1989). Zazula et al. (2009) added its presumed stratigraphic assignment based on a personal communication by S. Dallimore in 2008, who recovered this find "from sand and silt stratigraphically above" the uppermost ice-thrust marine sediment unit under thin veneer of loose colluvium (Zazula et al., 2009) and therefore suggested an in situ origin.

Table 5

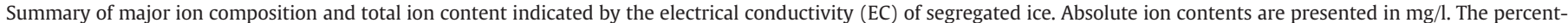
ages of individual anion and cation species are given as per cent of the total anion or cation population.

\begin{tabular}{|c|c|c|c|c|c|c|c|c|c|c|c|c|c|c|c|c|}
\hline \multirow[t]{2}{*}{ Profile } & & \multirow{2}{*}{$\begin{array}{l}\begin{array}{l}\text { Electrical } \\
\text { conductivity }\end{array} \\
{[\mu \mathrm{S} / \mathrm{cm}]}\end{array}$} & \multirow{2}{*}{$\begin{array}{l}\mathrm{Cl}^{-} \\
\overline{[\%]}\end{array}$} & \multirow{2}{*}{$\begin{array}{l}\mathrm{SO}_{4}^{2-} \\
\frac{\%]}{\%}\end{array}$} & \multirow{2}{*}{$\begin{array}{l}\mathrm{HCO}_{3}^{-} \\
\frac{[\%]}{2}\end{array}$} & \multirow{2}{*}{$\begin{array}{l}\mathrm{Ca}^{2+} \\
\frac{}{[\%]}\end{array}$} & \multirow{2}{*}{$\begin{array}{l}\mathrm{K}^{+} \\
\overline{[\%]}\end{array}$} & \multirow{2}{*}{$\begin{array}{l}\mathrm{Mg}^{2+} \\
\frac{[\%]}{}\end{array}$} & \multirow{2}{*}{$\begin{array}{l}\mathrm{Na}^{+} \\
{[\%]}\end{array}$} & \multirow{2}{*}{$\begin{array}{l}\mathrm{Cl}^{-} \\
\overline{[\mathrm{mg} / \mathrm{l}]}\end{array}$} & \multirow{2}{*}{$\begin{array}{l}\mathrm{SO}_{4}^{2-} \\
{[\mathrm{mg} / \mathrm{l}]}\end{array}$} & \multirow{2}{*}{$\begin{array}{l}\mathrm{HCO}_{3}^{-} \\
\overline{[\mathrm{mg} / \mathrm{l}]}\end{array}$} & \multirow{2}{*}{$\begin{array}{l}\mathrm{Ca}^{2+} \\
\frac{\mathrm{mg} / \mathrm{l}]}{}\end{array}$} & \multirow{2}{*}{$\begin{array}{l}\mathrm{K}^{+} \\
\overline{[\mathrm{mg} / \mathrm{l}]}\end{array}$} & \multirow{2}{*}{$\begin{array}{l}\mathrm{Mg}^{2+} \\
\overline{[\mathrm{mg} / \mathrm{l}]}\end{array}$} & \multirow{2}{*}{$\begin{array}{l}\mathrm{Na}^{+} \\
\mathrm{mg} / \mathrm{l}]\end{array}$} \\
\hline & & & & & & & & & & & & & & & & \\
\hline \multirow[t]{3}{*}{ Komakuk Beach (unit A) } & Mean & 6083 & 66.5 & 28.2 & 5.3 & 21.0 & 0.4 & 26.2 & 52.4 & 1592 & 838 & 205 & 258 & 10.5 & 199 & 758 \\
\hline & Min. & 4990 & 42.4 & 17.4 & 3.2 & 16.9 & 0.4 & 26.1 & 45.9 & 838 & 578 & 133 & 224 & 8.64 & 177 & 590 \\
\hline & Max. & 7010 & 79.4 & 49.4 & 8.1 & 27.5 & 0.5 & 26.3 & 56.3 & 1996 & 1324 & 276 & 308 & 11.8 & 227 & 920 \\
\hline \multirow[t]{3}{*}{ Komakuk Beach (unit B) } & Mean & 8308 & 54.7 & 40.4 & 4.9 & 48.1 & 0.3 & 26.5 & 25.1 & 2464 & 885 & 196 & 667 & 8.15 & 289 & 599 \\
\hline & Min. & 2660 & 6.1 & 0.8 & 1.4 & 27.5 & 0.2 & 21.4 & 9.1 & 88.4 & 51.5 & 139 & 509 & 4.23 & 115 & 93.0 \\
\hline & Max. & 17,770 & 97.8 & 88.3 & 8.6 & 69.2 & 0.4 & 31.8 & 40.5 & 6475 & 1729 & 293 & 885 & 15.0 & 620 & 1495 \\
\hline \multirow[t]{3}{*}{ Komakuk Beach (unit $C_{1}$ ) } & Mean & 4280 & 36.6 & 47.8 & 15.5 & 51.2 & 0.4 & 31.6 & 16.7 & 713 & 1134 & 379 & 514 & 8.39 & 200 & 201 \\
\hline & Min. & 1808 & 15.6 & 10.2 & 2.6 & 40.6 & 0.4 & 26.2 & 11.3 & 139 & 275 & 121 & 255 & 4.36 & 79.1 & 88.8 \\
\hline & Max. & 6420 & 76.1 & 69.9 & 41.9 & 60.3 & 0.5 & 34.9 & 25.2 & 1506 & 1917 & 735 & 755 & 11.7 & 288 & 346 \\
\hline \multirow[t]{3}{*}{ Komakuk Beach (unit $C_{2}$ ) } & Mean & 929 & 18.1 & 5.8 & 76.1 & 69.0 & 0.2 & 22.8 & 8.0 & 159 & 119 & 162 & 115 & 0.72 & 26.4 & 36.8 \\
\hline & Min. & 206 & 1.9 & 0 & 0.1 & 51.4 & 0 & 14.6 & 3.1 & 1.61 & $<0.1$ & 4.73 & 23.7 & $<0.2$ & 7.47 & 2.56 \\
\hline & Max. & 5170 & 60.8 & 39.1 & 98.1 & 77.6 & 0.5 & 36.2 & 23.7 & 1204 & 1050 & 247 & 516 & 2.91 & 150 & 273 \\
\hline \multirow{3}{*}{$\begin{array}{l}\text { Herschel Island below thaw } \\
\text { unconformity (unit 2) }\end{array}$} & Mean & 6635 & 86.7 & 7.4 & 5.9 & 5.6 & 1.9 & 11.8 & 80.7 & 2132 & 214 & 177 & 83.9 & 47.1 & 118 & 1293 \\
\hline & Min. & 949 & 25.0 & 0.1 & 1.6 & 1.5 & 1.2 & 6.5 & 44.6 & 213 & 5.50 & 44.1 & 6.91 & 7.24 & 6.47 & 164 \\
\hline & Max. & 14,610 & 97.8 & 47.2 & 27.8 & 24.6 & 3.6 & 27.1 & 89.6 & 4671 & 1328 & 480 & 419 & 109 & 375 & 2715 \\
\hline \multirow{3}{*}{$\begin{array}{l}\text { Herschel Island above thaw } \\
\text { unconformity (unit } 3 \text { and } 4 \text { ) }\end{array}$} & Mean & 4563 & 47.1 & 12.5 & 40.4 & 28.5 & 2.5 & 22.3 & 46.7 & 1290 & 376 & 215 & 168 & 25.9 & 107 & 703 \\
\hline & Min. & 136 & 5.4 & 0 & 1.9 & 8.5 & 0.9 & 12.2 & 8.4 & 6.05 & $<0.1$ & 65.3 & 13.3 & 2.92 & 4.48 & 7.25 \\
\hline & Max. & 14,300 & 90.2 & 39.5 & 94.6 & 58.7 & 4.9 & 34.0 & 73.7 & 4751 & 2019 & 396 & 540 & 75.0 & 354 & 2505 \\
\hline
\end{tabular}

a Includes data from Fritz et al. (2011). 
Table 6

Freshwater ostracod taxa from sediment samples of the Komakuk profiles. Species nomenclature follows Swain (1963), Delorme (1968) and Smith and Delorme (2010).

Ostracod taxa

Occurrence in unit

Cytherissa lacustris (sars, 1863)

Juvenile Candoninae

Candona candida (müller, 1776)

Candona rectangulata (alm, 1914)

Fabaeformiscandona caudata (kaufmann, 1900)

Cypria exsculpta (fischer, 1855)

Limnocythere camera (delorme, 1967)

Limnocytherina sanctipatricii (brady and robertson, 1969)

Limnocythere sp.

Ilyocypris biplicata (koch, 1838)

$\mathrm{C}_{1}$

A, B, $C_{1}, C_{2}$

$\mathrm{C}_{1}, \mathrm{C}_{2}$

$\mathrm{C}_{2}$

$\mathrm{C}_{2}$

A, $C_{1}, C_{2}$

$\mathrm{C}_{2}$

$\mathrm{C}_{2}$

$\mathrm{C}_{2}$

$\mathrm{C}_{1}, \mathrm{C}_{2}$

Other dates on allochthonous fossil vertebrates as young 20.5 to 19.9 cal ka BP from Herschel Island coasts demonstrate that terrestrial mammals lived and died on the YCP and the adjacent exposed shelf, and were incorporated into deposits that were later ice-thrust by a Late Wisconsinan advance of the LIS (Zazula et al., 2009). Similarly, Mackay and Dallimore (1992) suggested a short-lived regional ice advance to the Tuktoyaktuk Coastlands between $\sim 17$ to $15 \mathrm{cal}$ ka BP on the basis of dated postglacial lacustrine sediments and massive ground ice. This interpretation coincides with other evidence for an extensive northwest LIS during the Late Wisconsinan reported from surrounding areas including: the Tuktoyaktuk Coastlands (Dallimore et al., 1997; Murton et al., 1997; Bateman and Murton, 2006; Murton et al., 2007), Banks Island (England et al., 2009), and the Richardson and Mackenzie mountains (Duk-Rodkin and Hughes, 1995; Duk-Rodkin et al., 1996; Dyke et al., 2002; Kennedy et al., 2010).

However, the existing chronology of the northwestern part of the LIS is still under debate, although it is essential for delineating the eastern margin of Beringia and for assessing the climatic influence of the ice cap on east Beringian landscapes.

\subsubsection{Depositional environment}

The proximal ice margin likely supplied vast amounts of meltwater to the unglaciated parts of the YCP and the adjacent exposed continental shelf west of Herschel Island. Unit A at Komakuk Beach that is beyond the LIS limit represents an alluvial plain fed by meltwater in combination with proluvial sediment supply from the gentle foothill slopes of the Buckland Hills and the British Mountains. This together led to deposition of a distal sequence of fines dating to $20.7 \mathrm{cal} \mathrm{ka} \mathrm{BP}$ and $16.2 \pm 1.7 \mathrm{ka}$ (IRSL) (Fig. 10a). A freshwater facies is supported by the occurrence of freshwater ostracods (Cypria exsculpta, juvenile Candoninae) and by $\delta^{13} \mathrm{C}$ values around $-25 \%$ o that indicate a terrestrial carbon source. We infer low bioproductivity according to organic matter parameters and the sparseness of ostracods, which could be due either to running water, harsh climate conditions or a combination of both factors. Moderately enriched ion contents probably originated from sediments similar to the ion-rich deposits that presently occur on Herschel Island.

As the meltwater input ceased due to further retreat of the LIS margin, eolian input of loess-like calcareous fine-sandy silt identified by a more pronounced peak in the coarse silt fraction and a relatively high $\mathrm{CaCO}_{3}$ content (Fig. 4) - provided the sediment source for unit B between 17.7 and 11.3 cal ka BP (Fig. 10b). Strong eolian activity during late-glacial times is also recorded from the Tuktoyaktuk Coastlands (Murton et al., 1997; Bateman and Murton, 2006; Murton et al., 2007), the interior Yukon (Lauriol et al., 2002), and Northern Alaska (Carter, 1981, 1983; Dinter et al., 1990). The source area for this deflation may have been the exposed shelf, which would have been characterized by fine-grained calcareous deposits similar to those upthrust on Herschel Island. Higher ion contents of marine-related elements in unit B further support this interpretation (Table 5). In contrast to the large sand seas and dune fields in Northern Alaska and the Tuktoyaktuk Coastlands (Carter, 1981; Murton, 2009), substantial areas along the YCP may have been protected from eolian transport by cohesive tills (Bateman and Murton, 2006). Moreover, the source area for eolian sediment supply was probably smaller than other parts of the Arctic Coastal Plain due to the narrow shelf adjacent to the Mackenzie Trough that persisted during the sea level lowstand of the LGM (Fig. 1). The alluvialproluvial and eolian sediments of unit A and B at Komakuk Beach are structureless, probably as a result of permafrost and ground ice aggradation in moist deposits.

\subsubsection{Ground ice development}

The Late Wisconsinan episode of ice-wedge formation and permafrost aggradation along Komakuk Beach occurred prior to $11.2 \mathrm{cal}$ ka BP and largely simultaneously with the deposition of unit B as these sediments were IRSL dated to $12.3 \pm 1.3 \mathrm{ka}$ (see Fig. 10b). This might be coincident with extensive late glacial ice-wedge development prior to the end of the Younger Dryas cold interval as recorded in the Barrow region, northern Alaska (Meyer et al., 2010). The infilling material of ice-wedge casts along Komakuk Beach accumulated after the melt-out of ice wedges when thermokarst, peat accumulation, and organic-rich lacustrine deposition was initiated during the early Holocene (Fig. 10c, Table 2).

Although completely degraded along Komakuk Beach, remnants of Late Wisconsinan ice wedges (Fig. 10b and c) have been preserved on Herschel Island in sediments older than 16.2 cal ka BP. Narrow icewedge roots with silty ice fillings have been truncated by a distinct thaw unconformity. These ice wedges show a $\delta^{18} \mathrm{O}$ signature depleted by 5 to $7 \%$ and $d$-excess values that are 7 to $9 \%$ o lower than those of Holocene ice wedges which range from -25.5 to $-20.5 \%$ (Fig. 9, Table 4; see also Mackay, 1983; Burn et al., 1986; Michel, 1990). Similar low $\delta^{18} \mathrm{O}$ values, generally below $-26 \%$ and as low as $-32 \%$, have been reported for pre-Holocene ice wedges from Herschel Island (Michel, 1990), the Tuktoyaktuk Peninsula (Mackay, 1983), the central Yukon (Burn et al., 1986; Kotler and Burn, 2000), and Barrow, Alaska (Meyer et al., 2010). These isotopic values $\left(\delta^{18} \mathrm{O} \leq-26 \%\right.$ ), which are consistent with our signatures from Late Wisconsinan ice wedges, suggest reduced winter temperatures during snow formation. Although winter temperatures increased after $16 \mathrm{cal} \mathrm{ka} \mathrm{BP,}$ lower-than modern January temperatures still persisted in east Beringia until 13 cal ka BP (Viau et al., 2008). Ice wedges and fossil beetle assemblages from northern Alaska record a large-scale cooling of winter and summer temperatures between 12.8 and $11.5 \mathrm{cal} \mathrm{ka} \mathrm{BP,}$ coincident with the Younger Dryas cold interval (Elias, 2000; Meyer et al., 2010; Fritz et al., under review).

The limited occurrence of Late Wisconsinan ice wedges may have been due to low moisture supply in winter (Kotler and Burn, 2000) triggered by an extensive sea-ice cover on the Beaufort Sea until $\sim 9$ cal ka BP (Schell et al., 2008) in combination with a lowered glacio-eustatic sea level, displacing the coastline northward (Burn, 1997; Bateman and Murton, 2006; Murton and Bateman, 2007). Murton (1996) concluded that a trend from sediment-rich fillings of Late Wisconsinan ice wedges to sediment-poor Holocene wedges (cf. Kanevskiy et al., 2011) may record an environmental change from polar-desert conditions to more mesic tundra during the Holocene. Dry winter conditions during the Late Wisconsinan would also contribute to lowered $d$-excess values in associated ice wedges due to a larger water loss by sublimation from a thin snow pack (i.e. kinetic fractionation). This would lead to a snow pack that becomes successively depleted in ${ }^{16} \mathrm{O}$ compared to the initial precipitation. Alternatively, these depleted values may also be the product of a moisture source different from the present. Today, North Pacific winter sea surface temperatures (SSTs) control the moisture content and temperature of air masses that move northwestward across the study area (Bartlein et al., 1991), and therefore any change in their trajectory has the potential to change the $d$-excess signal. Mann and Hamilton (1995) suggested that a cooling of North Pacific waters 


\section{Komakuk Beach}

a) Late Wisconsinan; > 16 cal BP

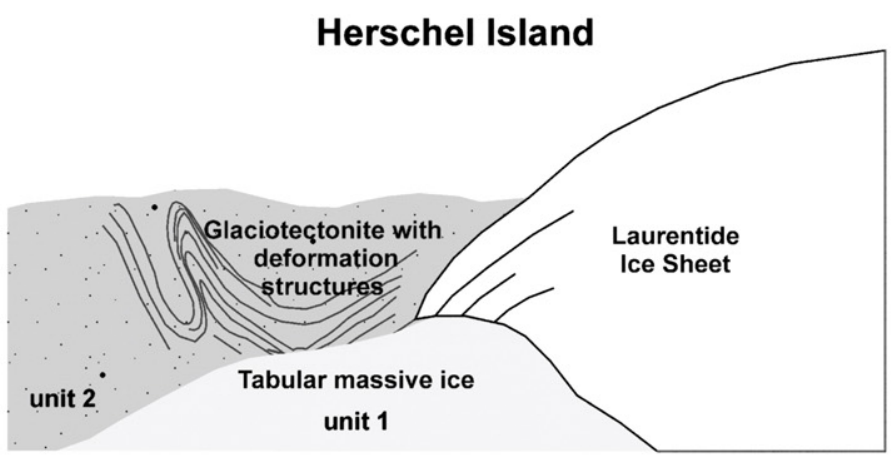

\section{b) Late Wisconsinan; 16 to $11.3 \mathrm{cal} \mathrm{BP}$}
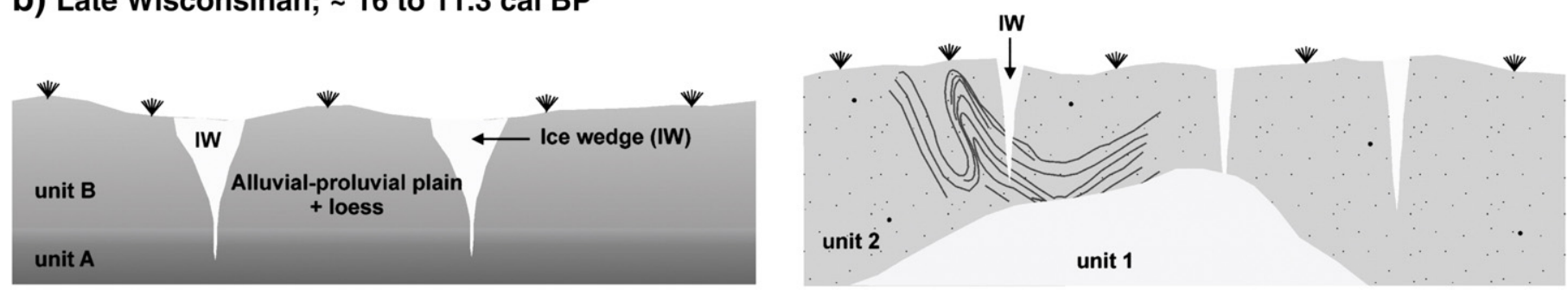

\section{c) Early Holocene; 11.2 to 6.5 cal BP}
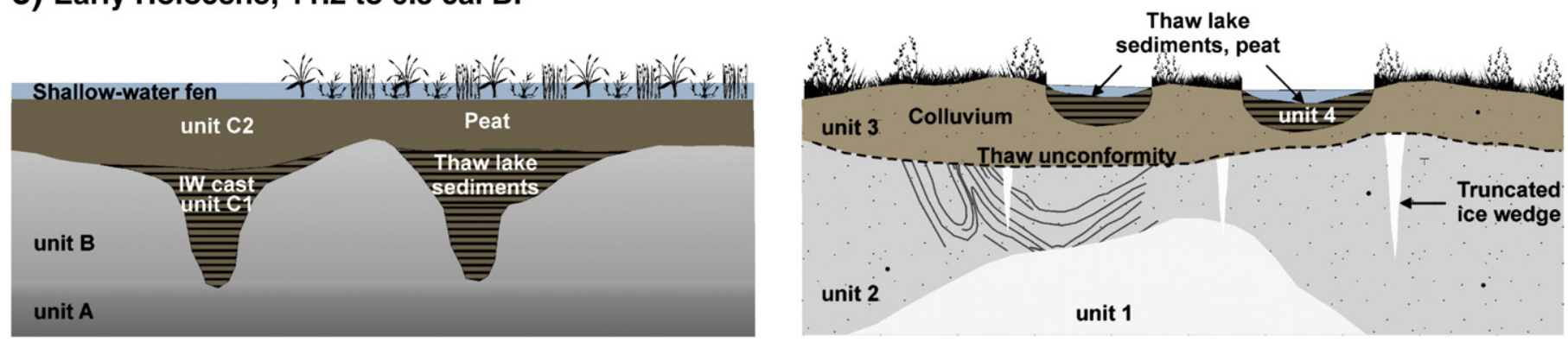

\section{d) Middle to Late Holocene; 6.5 cal BP to present}
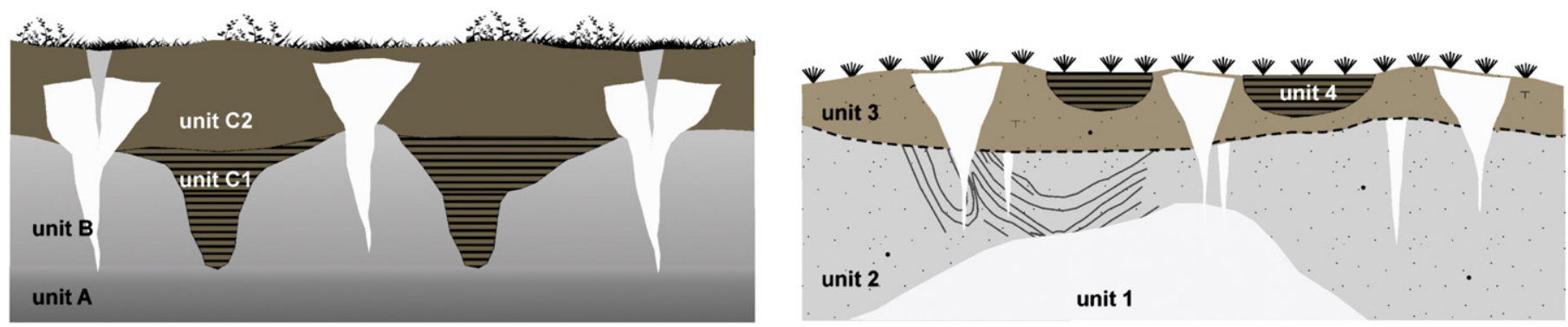

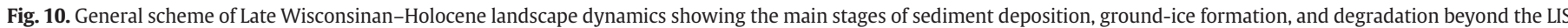
maximum extent (Komakuk Beach) and within the LIS extent (Herschel Island).

during the LGM and the Younger Dryas may have intensified the Polar Front as well as the Aleutian Low. They were shifted southward along with the southward limit of the sea-ice boundary (Bradley and England, 2008) reducing $d$-excess values until late glacial times due to higher humidity and/or lower SSTs.

\subsection{Early Holocene Thermal Maximum}

\subsubsection{Regional evidence}

A precession-driven summer insolation maximum $\sim 12$ to $10 \mathrm{cal}$ ka BP, in combination with the waning LIS, led to a warmer- than-modern period across large parts of the western Arctic (Ritchie et al., 1983; Kaufman et al., 2004) known as the Holocene Thermal Maximum (HTM). Western arctic Canada experienced maximum summer warmth beginning $~ 10.6$ cal ka BP (Kaufman et al., 2004) with a cooling to near-modern conditions between 6.7 and 5.6 cal ka BP (Cwynar and Spear, 1995). A rapidly transgressing sea from its regional minimum of $\sim 140 \mathrm{~m}$ below present during the LGM (Hill et al., 1985) combined with a decreasing sea ice cover (Schell et al., 2008) might have attenuated rising summer temperatures (Burn, 1997). This would have delivered more moisture to a formerly continental area that evolved into a coastal 
maritime environment (Kaufman et al., 2004). However, bathymetric charts indicate a relatively narrow continental shelf near Herschel Island, and a shoreline only 4 to $15 \mathrm{~km}$ north of the island by the early Holocene (Matthews, 1975). Hence, an arctic maritime climate was already influencing Herschel Island in the early Holocene.

Nevertheless, evidence for warmer and wetter conditions than today are widespread at both study sites, supporting previous investigations of thermokarst terrain, peatland development, and vegetation shifts in the western Canadian Arctic and on the North Slope, Alaska. For example, palynological data and dated spruce stumps found in situ on the Tuktoyaktuk Peninsula indicate that the treeline was 75 to $100 \mathrm{~km}$ north of its present position between approximately 10.2 and 5.7 cal ka BP (Ritchie, 1984). Dates on Populus wood from northern Alaska and northwestern Canada, found beyond its present range, and peaks in Populus pollen percentages from lake sediments suggest that Populus trees - which indicate substantially warmer conditions than today - had expanded into the area between 11.4 and 8.1 cal ka BP (Cwynar, 1982; Nelson and Carter, 1987; Anderson, 1988; Vermaire and Cwynar, 2010), and probably as early as 13.4 cal ka BP on favorable sites (Mann et al., 2002). Burn (1997) noted that summer warming was also due to the more northerly position of the coast at this time, allowing sites presently near the coast to experience greater continentality. Furthermore, Matthews (1975) described an insect fauna indicative of a warmer-than-modern climate, collected from an autochthonous peat lens east of Komakuk Beach (see Clarence Lagoon, Fig. 2) that dated $12.8 \mathrm{cal}$ ka BP. The Clarence Lagoon assemblage is comparable with other fossil beetle and ostracod assemblages from the early Holocene and even from the end of the late-glacial period in eastern Beringia (Delorme et al., 1977; Elias, 2001).

\subsubsection{Thermokarst and thaw unconformity}

Melt-out of ice wedges due to active layer deepening and peat growth along Komakuk Beach started around 11.3 cal ka BP as indicated by a dated basal peat samples (unit $C_{2}$ ), which cover the late-glacial alluvial-proluvial and eolian silts of unit B (Fig. 10). Organic-rich deposits containing freshwater mollusks and ostracods within an ice-wedge cast (unit $C_{1}$ ) yielded ages between 11.2 and 10.2 cal ka BP, supporting a rapid transition from an alluvial plain, unfavorable for plant growth and organic matter preservation, to a wetland tundra with standing water in thermokarst ponds or lakes (Fig. 10c; Vardy et al., 1997). Peat growth along Komakuk Beach was extensive at least until $6.7 \mathrm{cal} \mathrm{ka} \mathrm{BP}$, gradually slowing afterwards.

Rampton $(1982,1988)$ argued that higher summer temperatures and increased effective moisture led to the onset of thermokarst on the YCP and the Tuktoyaktuk Coastlands, peaking between 12.1 and $10.3 \mathrm{cal}$ ka BP. Ice-wedge growth would have been reduced or absent (Mackay, 1992; Murton and Bateman, 2007; Murton, 2009) during such a period of near-surface permafrost thaw and thermokarst lake development. Active-layer deepening to as much as 1.5 to $3.0 \mathrm{~m}$ below the modern surface is recorded on Herschel Island (Figs. 6 and 10c) and in the western Canadian Arctic by truncated ice wedges and a prominent unconformity due to this greater thaw depth (e.g. Burn et al., 1986; Harry et al., 1988; Murton and French, 1994) Burn (1997) estimated that the palaeoactive layer reached its maximum depth around 9 to $10 \mathrm{cal} \mathrm{ka} \mathrm{BP}$ and was up to 2.5 times greater than modern active-layer depths. On Herschel Island, Moorman et al. (1996) reported radiocarbon dates from the base of peat to be 12.8 and $10.4 \mathrm{cal} \mathrm{ka} \mathrm{BP,} \mathrm{whereas} \mathrm{Rampton} \mathrm{(1982)} \mathrm{dated} \mathrm{peat} \mathrm{in} \mathrm{a} \mathrm{drained}$ thaw pond to $10.7 \mathrm{cal} \mathrm{ka} \mathrm{BP}$. This coincides with three dates between 11.7 and 9.5 cal ka BP near the base of the palaeoactive layer on Herschel Island. Rising TOC contents in diamictons on Herschel Island occur above the thaw unconformity (unit 3 ) and suggest that organic material was incorporated during deep thaw, cryoturbation, and mass movement (Fig. 10c; Kokelj et al., 2002).

\subsubsection{Ground ice and hydrochemistry in the palaeoactive layer}

Higher $\delta^{18} \mathrm{O}$ values in segregated ice above the early Holocene thaw unconformity document either changing fractionation processes during multiple freeze-thaw cycles or multiple water sources (Mackay, 1983; French, 1998). We assume that as the active layer deepened under warmer climate conditions, Holocene summer and winter precipitation became mixed with Pleistocene meltwater (depleted in ${ }^{18} \mathrm{O}$ ) above the thaw unconformity (Lacelle et al., 2004; Fritz et al., 2011). This mixing resulted in a $\delta^{18} \mathrm{O}$ isotope composition ranging from -25.2 to $-17.1 \%$. The reduced amount of marinederived $\mathrm{Na}^{+}$and $\mathrm{Cl}^{-}$from upthrust marine sediments versus terrestrial ions such as $\mathrm{Ca}^{2+}, \mathrm{Mg}^{2+}$, and $\mathrm{HCO}_{3}^{-}$above the thaw unconformity, supports mixing with surface waters during the deep thaw period. Kokelj and Burn (2005) reported similar hydrochemical trends in freshwater environments overlying brackish deposits in the Mackenzie Delta.

\subsection{Middle and late Holocene permafrost aggradation}

Evidence from northern Alaska and northwestern Canada indicates re-initiation of ice-wedge growth, permafrost aggradation, and thawlake drainage in response to climate cooling following the HTM and persisting until at least the mid 20th century (Ritchie, 1984; Mackay, 1992; Eisner et al., 2003). In response to this cooling, the northernmost treeline shifted southwards, reaching its present position at about $4.5 \mathrm{cal}$ ka BP (Ritchie, 1984). Cwynar and Spear (1995) noted that green alder and black spruce pollen increased in abundance throughout the northern Yukon between 6.5 and $6.0 \mathrm{cal} \mathrm{ka}$ BP. The mid-Holocene spread of both taxa was probably promoted by a cooler and wetter climate, leading to paludification and rising permafrost tables (Cwynar and Spear, 1995).

Since the middle Holocene, both study sites have been dominated by the formation of extensive ice wedges with $\delta^{18} \mathrm{O}$ values centered around -23 to $-22 \%$, aligned close to the GMWL. This indicates relatively stable conditions in terms of moisture source, frost-crack infill, and O-H isotope signal preservation (St-Jean et al., 2011). This is similar to observations made by Michel and Fritz (1982) and Mackay (1983) who noted that ice wedges in the Tuktoyaktuk Coastlands have 3 to $5 \%$ o lower $\delta^{18} \mathrm{O}$ values, compared to the mean annual precipitation, which Michel and Fritz (1982) deduced to be the isotope composition of groundwater in the modern active layer $(-20$ to $-18 \%$ ).

$\delta^{18} \mathrm{O}$ values of segregated ice within peat (unit $\mathrm{C}_{2}$ ) along Komakuk Beach increase continuously upward from -20.3 to $-14.0 \%$ ond are accompanied by a decreasing $d$-excess from 4.9 to $-8.2 \%$. These parameters together point toward strong kinetic fractionation effects. Non-equilibrium evaporation results in the enrichment of heavy isotopes $\left({ }^{18} \mathrm{O},{ }^{2} \mathrm{H}\right)$, and concurrently reduces the $d$-excess of the remaining water along a so-called evaporation line with a slope value significantly lower than the GMWL (Dansgaard, 1964; Gat, 1996). The resulting regression slope of $6.0\left(R^{2}=0.99\right)$ might be due to decreasing water availability as a consequence of changed hydrological conditions together with a higher selective water loss by evaporation. Vardy et al. (1997) suggested that organic matter accumulation and continued ground-ice growth since the middle Holocene probably raised the surface of the Kukjuk Peatland (Tuktoyaktuk Peninsula). The changing isotopic signature within the peat at Komakuk Beach may indicate an environmental change that supported the development of such an ombrogenous peatland (Vardy et al., 1998). The former low-centered polygons were converted into high-centered polygons, with improved drainage into the ice-wedge troughs. Lower summer temperatures in response to a long-term regional cooling (Viau et al., 2008; Bunbury and Gajewski, 2009) and permafrost aggradation (Vardy et al., 1997) may have led to reduced peat growth and lower carbon accumulation rates during the last $4 \mathrm{ka}$ (Vardy et al., 2000; Eisner et al., 2003). 
Recent permafrost conditions are probably best explained by the occurrence and size of rejuvenated ice-wedges along Komakuk Beach. There, the tops of the primary wedges ( $1 \mathrm{~m}$ below surface) mark the base of a former permafrost table that is possibly a thaw unconformity of unknown age but post HTM. Since then, the upward aggradation of permafrost has led to ice-wedge rejuvenation, indicated by new growth stages extending upward to the modern frost table (Harry et al., 1985). This renewed growth has probably developed in response to a climate cooling trend (Mackay, 1976), and the small size of these veinlets $(0.25 \mathrm{~m})$ suggests that active layer thinning is a relatively young phenomenon in this area (Harry et al., 1985).

\section{Conclusions}

The following conclusions can be drawn from this study:

1. Late Wisconsinan Laurentide ice reached its maximum extent, near the Herschel Island area, by 16.2 cal ka BP.

2. While Herschel Island was ice-covered during the Late Wisconsinan, the westernmost part of the YCP remained ice-free, constituting the easternmost edge of Beringia, where organic remains date from the LGM. This part of Beringia developed from a barren alluvial-proluvial plain with actively aggrading permafrost during the LGM and the late glacial ( 21 to $11.3 \mathrm{cal} \mathrm{ka}$ BP) to a wet thermokarst landscape with the onset of the HTM.

3. Warmer-than-modern summer temperatures during the HTM (11.2 to $6.5 \mathrm{cal}$ ka BP) resulted in thaw of ice-rich near-surface permafrost and melt-out of ice wedges. Thermokarst processes were accompanied by lacustrine deposition in shallow depressions that have been subsequently preserved within ice-wedge casts. Extensive peat growth on a low-centered polygonal tundra proceeded in easternmost Beringia until the middle Holocene.

4. Different ice-wedge generations serve as a palaeoenvironmental indicator of certain episodes of permafrost aggradation while icewedge casts, thaw unconformities, and truncated ice wedges record permafrost degradation along the YCP since the Late Wisconsinan.

5. Pre-Holocene and Holocene ice wedges coexist on Herschel Island and are clearly differentiated by their stable $\mathrm{O}-\mathrm{H}$ isotope composition and ground-ice stratigraphy. $\delta^{18} \mathrm{O}$ and $d$-excess values of Late Wisconsinan ice wedges reflect reduced winter temperatures during snow formation, and probably dryer continental conditions than those having occurred from the middle Holocene until today. Exposure of the continental shelf during the LGM and severe sea ice on the Arctic Ocean contributed to greater aridity.

6. Permafrost aggradation and extensive ice-wedge growth in the western Canadian Arctic resulted from mid-Holocene climate cooling.

In summary, we conclude that the glacial-interglacial landscape dynamics along the YCP (eastern Beringia) are closely linked to LIS history, sea-level variations, and permafrost development over time in general, as well as to ground-ice aggradation and thermokarst processes in particular.

\section{Acknowledgments}

The authors wish to express their thanks to the Yukon Territorial Government, the Yukon Parks (Herschel Island Qiqiktaruk Territorial Park), and the Yukon Department of Renewable Resources for their support during this project. We acknowledge the support of the Polar Continental Shelf Program (PCSP/ÉPCP) and the Aurora Research Institute (ARI) for the field component. This study was partly funded by the German Science Foundation (DFG, Project No. LA 2399/3-1), the German Federal Ministry of Education and Research (BMBF, Project No. CAN 08/A07, CAN 09/001) and by a doctoral fellowship awarded to M. Fritz by the German Federal Environmental Foundation (DBU). Analytical work received great support from A. Eulenburg, U. Bastian, C. Funk, and L. Schönicke in the laboratories at the Alfred Wegener Institute Potsdam and from B. Plessen at the German Research Centre for Geosciences (GFZ). N. Couture (GSC, Ottawa), N. Arkell, and M. Angelopulos (McGill University, Montreal) assisted in the field. C. O'Connor (UAF, Fairbanks, Alaska) is thanked for language revision. We finally thank J.B. Murton and J. England for very constructive suggestions that improved the paper.

\section{Appendix A. Supplementary material}

Supplementary data to this article can be found online at doi:10. 1016/j.palaeo.2011.12.015.

\section{References}

Abbott, M.B., Edwards, M.E., Finney, B.P., 2010. A 40,000-yr record of environmental change from Burial Lake in Northwest Alaska. Quaternary Research 74, 156-165. doi:10.1016/j.yqres.2010.03.007.

Ager, T.A., 2003. Late Quaternary vegetation and climate history of the central Bering land bridge from St. Michael Island, western Alaska. Quaternary Research 60, 19-32. doi:10.1016/S0033-5894(03)00068-1.

Anderson, P.M., 1985. Late quaternary vegetational change in the Kotzebue Sound area, northwestern Alaska. Quaternary Research 24, 307-321. doi:10.1016/0033-5894 (85)90053-5.

Anderson, P.M., 1988. Late quaternary pollen records from the Kobuk and Noatak river drainages, northwestern Alaska. Quaternary Research 29, 263-276. doi:10.1016/ 0033-5894(88)90035-X.

Anderson, P.M., Bartlein, P.J., Brubaker, L.B., 1994. Late Quaternary history of tundra vegetation in Northwestern Alaska. Quaternary Research 41, 306-315. doi:10.1006/qres.1994.1035.

Ayles, G.B., Snow, N.B., 2002. Canadian Beaufort Sea 2000: the environmental and social setting. Arctic 55 (Suppl. 1), 4-17.

Barendregt, R.W., Duk-Rodkin, A., 2004. Chronology and extent of Late Cenozoic ice sheets in North America: a magnetostratigraphic assessment. In: Ehlers, J., Gibbard P.L. (Eds.), Developments in Quaternary Science. Elsevier, Amsterdam, pp. 1-7. doi:10.1016/S1571-0866(04)80181-7.

Bartlein, P.J., Anderson, P.M., Edwards, M.E., McDowell, P.F., 1991. A framework for interpreting paleoclimatic variations in Eastern Beringia. Quaternary International 10-12, 73-83. doi:10.1016/1040-6182(91)90041-L.

Bateman, M.D., Murton, J.B., 2006. Late Pleistocene glacial and periglacial aeolian activity in the Tuktoyaktuk Coastlands, NWT, Canada. Quaternary Science Reviews 25, 2552-2568. doi:10.1016/j.quascirev.2005.07.023.

Berger, G.W., Anderson, P.M., 1994. Thermoluminescence dating of an Arctic lake core from Alaska. Quaternary Science Reviews 13, 497-501. doi:10.1016/0277-3791 (94)90065-5.

Black, R.F., 1964. Gubik Formation of Quaternary age in northern Alaska. U.S. Geological Survey Professional Paper 302-C, pp. 59-91.

Blasco, S.M., Fortin, G., Hill, P.R., O'Connor, M.J., Brigham-Grette, J., 1990. The late Neogene and Quaternary stratigraphy of the Canadian Beaufort continental shelf. In: Grantz, A Johnson, L., Sweeney, J.F. (Eds.), The Geology of North America. Vol. L: The Arctic Ocean Region. Geological Society of America, Boulder, Colorado, pp. 491-502.

Bouchard, M., 1974. Géologie des dépôts meubles de l'île Herschel, territoire du Yukon. M.Sc. (maitrise) thesis. Université de Montréal (in French)

Bradley, R.S., England, J.H., 2008. The Younger Dryas and the sea of ancient ice. Quaternary Research 70, 1-10. doi:10.1016/j.yqres.2008.03.002.

Brigham-Grette, J., Carter, D.L., 1992. Pliocene marine transgressions of Northern Alaska: circumarcitc correlations and paleoclimatic implications. Arctic 45, 74-89.

Bunbury, J., Gajewski, K., 2009. Postglacial climates inferred from a lake at treeline, southwest Yukon Territory, Canada. Quaternary Science Reviews 28, 354-369. doi:10.1016/j.quascirev.2008.10.007.

Burn, C.R., 1997. Cryostratigraphy, paleogeography, and climate change during the early Holocene warm interval, western Arctic coast, Canada. Canadian Journal of Earth Sciences 34, 912-925. doi:10.1139/e17-076.

Burn, C.R., Michel, F.A., Smith, M.W., 1986. Stratigraphic, isotopic, and mineralogical evidence for an early Holocene thaw unconformity at Mayo, Yukon Territory. Canadian Journal of Earth Sciences 23, 794-801. doi:10.1139/e86-081.

Carter, L.D., 1981. A Pleistocene Sand Sea on the Alaskan Arctic Coastal Plain. Science 211, 381-383. doi:10.1126/science.211.4480.381.

Carter, L.D., 1983. Fossil sand wedges on the Alaskan Arctic Coastal Plain and their paleoenvironmental significance. Proceedings of the Fourth International Conference on Permafrost, 17-22 July 1983, Fairbanks, USA. National Academy Press, Washington D.C, pp. 109-114.

Craig, H., 1961. Isotopic variations in meteoric waters. Science 133, 1702-1703. doi:10.1126/science.133.3465.1702.

Cwynar, L.C., 1982. A Late-Quaternary vegetation history from Hanging Lake, Northern Yukon. Ecological Monographs 52, 1-24.

Cwynar, L.C., Spear, R.W., 1995. Paleovegetation and paleoclimatic changes in the Yukon at 6 ka BP. Géographie Physique et Quaternaire 49, 29-35. 
Dallimore, S.R., Wolfe, S.A., Matthews Jr., J.V., Vincent, J.-S., 1997. Mid-Wisconsinan eolian deposits of the Kittigazuit Formation, Tuktoyaktuk Coastlands, Northwest Territories, Canada. Canadian Journal of Earth Sciences 34, 1421-1441. doi:10.1139/ e17-116.

Dansgaard, W., 1964. Stable isotopes in precipitation. Tellus 16, 436-468. doi:10.1111/ j.2153-3490.1964.tb00181.x.

Delorme, L.D., 1968. Pleistocene freshwater ostracoda from Yukon, Canada. Canadian Journal of Zoology 46, 859-876. doi:10.1139/z68-123.

Delorme, L.D., Zoltai, S.C., Kalas, L.L., 1977. Freshwater shelled invertebrate indicators of paleoclimate in northwestern Canada during late glacial times. Canadian Journal of Earth Sciences 14, 2029-2046. doi:10.1139/e77-174.

Dinter, D.A., Carter, D.L., Brigham-Grette, J., 1990. Late Cenozoic geological evolution of the Alaskan North Slope and adjacent continental shelves. In: Grantz, A., Johnson, L., Sweeney, J.F. (Eds.), The Geology of North America. Vol. L: The Arctic Ocean Region. Geological Society of America, Boulder, Colorado, pp. 459-490.

Duk-Rodkin, A., Hughes, O.L., 1995. Quaternary geology of the northwest part of the central Mackenzie Valley corridor, Northwest Territories. Geological Survey of Canada Bulletin 458. . (Ottawa 45 pp.).

Duk-Rodkin, A., Barendregt, R.W., Tarnocai, C., Phillips, F.M., 1996. Late Tertiary to late Quaternary record in the Mackenzie Mountains, Northwest Territories, Canada: stratigraphy, paleosols, paleomagnetism and chlorine-36. Canadian Journal of Earth Sciences 33, 875-895. doi:10.1139/e96-066.

Duk-Rodkin, A., Barendregt, R.W., Froese, D.G., Weber, F., Enkin, R., Smith, I.R., Zazula, G.D., Waters, P., Klassen, R., 2004. Timing and extent of Plio-Pleistocene glaciation in north-western Canada and east-central Alaska. In: Ehlers, J., Gibbard, P.L. (Eds.), Developments in Quaternary Science. Elsevier, Amsterdam, pp. 313-345. doi:10.1016/S1571-0866(04)80206-9.

Dyke, A.S., Prest, V.K., 1987. Late Wisconsinan and Holocene history of the Laurentide Ice Sheet. Géographie Physique et Quaternaire 41, 237-263.

Dyke, A.S., Andrews, J.T., Clark, P.U., England, J.H., Miller, G.H., Shaw, J., Veillette, J.J. 2002. The Laurentide and Innuitian ice sheets during the Last Glacial Maximum. Quaternary Science Reviews 21, 9-31. doi:10.1016/S0277-3791(01)00095-6.

Eisner, W.R., 1991. Palynological analysis of a peat core from Imnavait Creek, the North Slope, Alaska. Arctic 44, 279-282.

Eisner, W.R., Colinvaux, P.A., 1990. A long pollen record from Ahaliorak Lake, Arctic Alaska. Review of Palaeobotany and Palynology 63, 35-52. doi:10.1016/00346667(90)90005-4.

Eisner, W.R., Hinkel, K.M., Bockheim, J.G., Nelson, F.E., 2003. Late-Quaternary paleoenvironmental record from a palsa-scale frost mound in arctic Alaska. Proceedings of the Eighth International Conference on Permafrost, 21-25 July 2003, Zürich, Switzerland. A.A. Balkema Publishers, Lisse, pp. 229-234.

Eisner, W.R., Bockheim, J.G., Hinkel, K.M., Brown, T.A., Nelson, F.E., Peterson, K.M., Jones, B.M., 2005. Paleoenvironmental analyses of an organic deposit from an erosiona landscape remnant, Arctic Coastal Plain of Alaska. Palaeogeography, Palaeoclimatology, Palaeoecology 217, 187-204. doi:10.1016/j.palaeo.2004.11.025.

Elias, S.A., 2000. Late Pleistocene climates of Beringia, based on analysis of fossil beetles. Quaternary Research 53, 229-235. doi:10.1006/qres.1999.2093.

Elias, S.A., 2001. Mutual climatic range reconstructions of seasonal temperatures based on Late-Pleistocene fossil beetle assemblages in Eastern Beringia. Quaternary Science Reviews 20, 77-91. doi:10.1016/S0277-3791(00)00130-X.

England, J.H., Furze, M.F.A., Doupé, J.P., 2009. Revision of the NW Laurentide Ice Sheet: implications for paleoclimate, the northeast extremity of Beringia, and Arcti Ocean sedimentation. Quaternary Science Reviews 28, 1573-1596. doi:10.1016/ j.quascirev.2009.04.006.

Fairbanks, R.G., 1989. A 17,000-year glacio-eustatic sea level record: influence of glacial melting rates on the Younger Dryas event and deep-ocean circulation. Nature 342 637-642. doi:10.1038/342637a0.

French, H.M., 1998. An appraisal of cryostratigraphy in north-west Arctic Canada. Permafrost and Periglacial Processes 9, 297-312. doi:10.1002/(SICI)1099-1530 (199810/12)9:4<297::AID-PPP296>3.0.CO;2-B

Fritz, M., Wetterich, S., Meyer, H., Schirrmeister, L., Lantuit, H., Pollard, W.H., 2011. Origin and characteristics of massive ground ice on Herschel Island (western Canadian Arctic) as revealed by stable water isotope and hydrochemical signatures Permafrost and Periglacial Processes 22, 26-38. doi:10.1002/ppp. 714.

Fritz, M., Herzschuh, U., Wetterich, S., Lantuit, H., De Pascale, G.P., Pollard, W.H. Schirrmeister, L. (under review). Late glacial and Holocene sedimentation, vegetation, and temperature history from easternmost Beringia (Northern Yukon Territory, Canada).

Gat, J.R., 1996. Oxygen and hydrogen isotopes in the hydrologic cycle. Annual Review of Earth and Planetary Sciences 24, 225-262. doi:10.1146/annurev.earth.24.1.225.

Hamilton, T.D., Ashley, G.M., 1993. Epiguruk: a late Quaternary environmental record from northwestern Alaska. Geological Society of America Bulletin 105, 583-602.

Hamilton, T.D., Ashley, G.M., Reed, K.M., Schweger, C.E., 1993. Late Pleistocene vertebrates and other fossils from Epiguruk, Northwestern Alaska. Quaternary Research 39, 381-389. doi:10.1006/qres.1993.1045.

Harington, C.R., 1989. Pleistocene vertebrate localities in the Yukon. In: Carter, L.D., Hamilton, T.D., Galloway, J.P. (Eds.), Late Cenozoic history of the Interior Basins of Alaska and the Yukon: U.S. Geological Survey Circular, 1026, pp. 93-98.

Harington, C.R., 2005. The eastern limit of Beringia: mammoth remains from Banks and Melville islands, Northwest Territories. Arctic 58, 361-369.

Harry, D.G., French, H.M., Pollard, W.H., 1985. Ice wedges and permafrost conditions near King Point, Beaufort Sea coast. Yukon Territory, Geological Survey of Canada, Paper 85-1A, pp. 111-116.

Harry, D.G., French, H.M., Pollard, W.H., 1988. Massive ground ice and ice-cored terrain near Sabine Point, Yukon Coastal Plain. Canadian Journal of Earth Sciences 25, 1846-1856. doi:10.1139/e88-174.
Hill, P.R., Mudie, P.J., Moran, K., Blasco, S.M., 1985. A sea-level curve for the Canadian Beaufort Shelf. Canadian Journal of Earth Sciences 22, 1383-1393. doi:10.1139/e85-146.

Hopkins, D.M., 1982. Aspects of the paleogeography of Beringia during the Late Pleistocene. In: Hopkins, D.M., Matthews Jr., J.V., Schweger, C.E., Young, S.B. (Eds.), Paleoecology of Beringia. Academic Press, New York, pp. 3-28.

Horita, J., Ueda, A., Mizukami, K., Takaton, I., 1989. Automatic $\delta \mathrm{D}$ and $\delta^{18} \mathrm{O}$ analyses of multi-water samples using $\mathrm{H}_{2}$ - and $\mathrm{CO}_{2}$-water equilibration methods with a common equilibration set-up. Applied Radiation and Isotopes 40, 801-805. doi:10.1016/0883-2889(89)90100-7.

Hughes, O., 1972. Surficial geology of northern Yukon Territory and northwestern District of Mackenzie, Northwest Territories. Geological Survey of Canada, Paper 6936. (11 pp.).

Hultén, E., 1937. Outline of the History of Arctic and Boreal Biota during the Quaternary Period. Bokförlags Aktiebolaget Thule, Stockholm.

IAEA (International Atomic Energy Agency), 2006. Isotope Hydrology Information System. The ISOHIS Database. http://www.iaea.org/water2006 (accessed January 2011).

Inman, D.L., 1952. Measures for describing the size distribution of sediments. Journal of Sedimentary Research 22, 125-145. doi:10.1306/d42694db-2b26-11d78648000102c1865d.

Jakobsson, M., Macnab, R., Mayer, L., Anderson, R., Edwards, M., Hatzky, J., Schenke, H.W., Johnson, P., 2008. An improved bathymetric portrayal of the Arctic Ocean: implications for ocean modeling and geological, geophysical and oceanographic analyses. Geophysical Research Letters 35, L07602. doi:10.1029/2008GL033520.

Kanevskiy, M., Shur, Y., Fortier, D., Jorgenson, M.T., Stephani, E., 2011. Cryostratigraphy of late Pleistocene syngenetic permafrost (yedoma) in northern Alaska, Itkillik River exposure. Quaternary Research 75, 584-596. doi:10.1016/j.yqres.2010.12.003.

Kaufman, D.S., Ager, T.A., Anderson, N.J., Anderson, P.M., Andrews, J.T., Bartlein, P.J., Brubaker, L.B., Coats, L.L., Cwynar, L.C., Duvall, M.L., Dyke, A.S., Edwards, M.E., Eisner, W.R., Gajewski, K., Geirsdottir, A., Hu, F.S., Jennings, A.E., Kaplan, M.R., Kerwin, M.W., Lozhkin, A.V., MacDonald, G.M., Miller, G.H., Mock, C.J., Oswald, W.W., OttoBliesner, B.L., Porinchu, D.F., Rühland, K., Smol, J.P., Steig, E.J., Wolfe, B.B., 2004. Holocene thermal maximum in the western Arctic (0-180-W). Quaternary Science Reviews 23, 529-560. doi:10.1016/j.quascirev.2003.09.007.

Kennedy, K.E., Froese, D.G., Zazula, G.D., Lauriol, B., 2010. Last Glacial Maximum age for the northwest Laurentide maximum from the Eagle River spillway and delta complex, northern Yukon. Quaternary Science Reviews 29, 1288-1300. doi:10.1016/ j.quascirev.2010.02.015

Kokelj, S.V., Burn, C.R., 2005. Geochemistry of the active layer and near-surface permafrost, Mackenzie delta region, Northwest Territories, Canada. Canadian Journal of Earth Sciences 42, 37-48. doi:10.1139/e04-089.

Kokelj, S.V., Smith, C.A.S., Burn, C.R., 2002. Physical and chemical characteristics of the active layer and permafrost, Herschel Island, western Arctic coast, Canada. Permafrost and Periglacial Processes 13, 171-185. doi:10.1002/ppp. 417.

Kotler, E., Burn, C.R., 2000. Cryostratigraphy of the Klondike "muck" deposits, westcentral Yukon Territory. Canadian Journal of Earth Sciences 37, 849-861. doi:10.1139/e00-013.

Kurek, J., Cwynar, L.C., Vermaire, J.C., 2009. A late Quaternary paleotemperature record from Hanging Lake, northern Yukon Territory, eastern Beringia. Quaternary Research 72, 246-257. doi:10.1016/j.yqres.2009.04.007.

Lacelle, D., Bjornson, J., Lauriol, B., Clark, I.D., Troutet, Y., 2004. Segregated-intrusive ice of subglacial meltwater origin in retrogressive thaw flow headwalls, Richardson Mountains, NWT, Canada. Quaternary Science Reviews 23, 681-696. doi:10.1016/ j.quascirev.2003.09.005

Lacelle, D., Lauriol, B., Clark, I.D., Cardyn, R., Zdanowicz, C., 2007. Nature and origin of a Pleistocene-age massive ground-ice body exposed in the Chapman Lake moraine complex, central Yukon Territory, Canada. Quaternary Research 68, 249-260. doi:10.1016/j.yqres.2007.05.002.

Lacelle, D., St-Jean, M., Lauriol, B., Clark, I.D., Lewkowicz, A., Froese, D.G., Kuehn, S.C., Zazula, G., 2009. Burial and preservation of a 30,000 year old perennial snowbank in Red Creek valley, Ogilvie Mountains, central Yukon, Canada. Quaternary Science Reviews 28, 3401-3413. doi:10.1016/j.quascirev.2009.09.013.

Lacourse, T., Gajewski, K., 2000. Late Quaternary vegetation history of Sulphur Lake, Southwest Yukon Territory, Canada. Arctic 63, 27-35.

Lantuit, H., Pollard, W.H., 2008. Fifty years of coastal erosion and retrogressive thaw slump activity on Herschel Island, southern Beaufort Sea, Yukon Territory, Canada. Geomorphology 95, 84-102. doi:10.1016/j.geomorph.2006.07.040.

Lantuit, H., Pollard, W.H., Couture, N., Fritz, M., Schirrmeister, L., Meyer, H., Hubberten, H.-W. (under review). Modern and Late Holocene retrogressive thaw slump activity on the Yukon Coastal Plain and Herschel Island, Yukon Territory, Canada.

Lauriol, B., Cabana, Y., Cinq-Mars, J., Geurts, M.-A., Grimm, F.W., 2002. Cliff-top eolian deposits and associated molluscan assemblages as indicators of Late Pleistocene and Holocene environments in Beringia. Quaternary International 87, 59-79. doi:10.1016/S1040-6182(01)00062-3.

Mackay, J.R., 1959. Glacier ice-thrust features of the Yukon Coast. Geographical Bulletin $13,5-21$

Mackay, J.R., 1971. The origin of massive icy beds in permafrost, western arctic coast, Canada. Canadian Journal of Earth Sciences 8, 397-422. doi:10.1139/e71-043.

Mackay, J.R., 1976. Ice-wedges as indicators of recent climatic change, western Arctic coast. Current Research, Geological Survey of Canada Paper 76-1A, pp. 233-234.

Mackay, J.R., 1983. Oxygen isotope variations in permafrost, Tuktoyaktuk Peninsula area, Northwest Territories. Geological Survey of Canada, Current Research Part B (Paper 83-1B), pp. 67-74

Mackay, J.R., 1992. The frequency of ice-wedge cracking (1967-1987) at Garry Island, western Arctic coast, Canada. Canadian Journal of Earth Sciences 29, 236-248. doi:10.1139/e92-022. 
Mackay, J.R., Dallimore, S.R., 1992. Massive ice of the Tuktoyaktuk area, western Arctic coast, Canada. Canadian Journal of Earth Sciences 29, 1235-1249. doi:10.1139/e92099.

Mann, D.H., Hamilton, T.D., 1995. Late Pleistocene and Holocene paleoenvironments of the North Pacific coast. Quaternary Science Reviews 14, 449-471. doi:10.1016/ 0277-3791(95)00016-I.

Mann, D.H., Peteet, D.M., Reanier, R.E., Kunz, M.L., 2002. Responses of an arctic landscape to Lateglacial and early Holocene climatic changes: the importance of moisture. Quaternary Science Reviews 21, 997-1021. doi:10.1016/S0277-3791(01) 00116-0.

Matthews Jr., J.V., 1975. Incongruence of macrofossils and pollen evidence: a case from the late Pleistocene of the northern Yukon Coast. Geological Survey of Canada, Report of Activities, Part B, Paper 75-1B, pp. 139-146.

Matthews Jr., J.V., Schweger, C.E., Hughes, O.L., 1990. Plant and insect fossils from the Mayo Indian Village section (Central Yukon): new data on Middle Wisconsinan environments and glaciation. Géographie Physique et Quaternaire 44, 15-26.

Meyer, H., Schönicke, L., Wand, U., Hubberten, H.-W., Friedrichsen, H., 2000. Isotope studies of hydrogen and oxygen in ground ice - experiences with the equilibration technique. Isotopes in Environmental and Health Studies 36, 133-149.

Meyer, H., Schirrmeister, L., Yoshikawa, K., Opel, T., Wetterich, S., Hubberten, H.-W., Brown, J., 2010. Permafrost evidence for severe winter cooling during the Younger Dryas in northern Alaska. Geophysical Research Letters 37, L03501. doi:10.1029/ 2009 GL041013.

Michel, F.A., 1990. Isotopic composition of ice-wedge ice in Northwestern Canada. Proceedings of the Fifth Canadian Permafrost Conference. Collection Nordicana, Quebec City, pp. 5-9.

Michel, F.A., Fritz, P., 1982. Significance of isotope variations in permafrost waters at Illisarvik, NWT. Proceedings of the Fourth Canadian Permafrost Conference, pp. 173-181.

Moorman, B.J., Michel, F.A., Wilson, A.T., 1996. ${ }^{14} \mathrm{C}$ dating of trapped gases in massive ground ice, western Canadian Arctic. Permafrost and Periglacial Processes 7, 257-266. doi:10.1002/(SICI)1099-1530(199609)7:3<257::AID-PPP220>3.0.CO;2-P.

Murton, J.B., 1996. Morphology and paleoenvironmental significance of Quaternary sand veins, sand wedges, and composite wedges, Tuktoyaktuk Coastlands, Western Arctic Canada. Journal of Sedimentary Research 66, 17-25. doi:10.1306/ d4268298-2b26-11d7-8648000102c1865d.

Murton, J.B., 2005. Ground-ice stratigraphy and formation at North Head, Tuktoyaktuk Coastlands, western Arctic Canada: a product of glacier-permafrost interactions. Permafrost and Periglacial Processes 16, 31-50. doi:10.1002/ppp. 513.

Murton, J.B., 2009. Stratigraphy and palaeoenvironments of Richards Island and the eastern Beaufort Continental Shelf during the last glacial-interglacial cycle. Permafrost and Periglacial Processes 20, 107-125. doi:10.1002/ppp. 647.

Murton, J.B., Bateman, M.D., 2007. Syngenetic sand veins and anti-syngenetic sand wedges, Tuktoyaktuk Coastlands, western Arctic Canada. Permafrost and Periglacial Processes 18, 33-47. doi:10.1002/ppp. 577.

Murton, J.B., French, H.M., 1994. Cryostructures in permafrost, Tuktoyaktuk Coastlands, western Arctic Canada. Canadian Journal of Earth Sciences 31, 737-747. doi:10.1139/e94-067.

Murton, J.B., French, H.M., Lamothe, M., 1997. Late Wisconsinan erosion and eolian deposition, Summer Island area, Pleistocene Mackenzie Delta, Northwest Territories: optical dating and implications for glacial chronology. Canadian Journal of Earth Sciences 34, 190-199. doi:10.1139/e17-015

Murton, J.B., Waller, R.I., Hart, J.K., Whiteman, C.A., Pollard, W.H., Clark, I.D., 2004. Stratigraphy and glaciotectonic structures of permafrost deformed beneath the northwest margin of the Laurentide Ice Sheet, Tuktoyaktuk Coastlands, Canada. Journal of Glaciology 50, 399-412. doi:10.3189/172756504781829927.

Murton, J.B., Whiteman, C.A., Waller, R.I., Pollard, W.H., Clark, I.D., Dallimore, S.R., 2005. Basal ice facies and supraglacial melt-out till of the Laurentide Ice Sheet, Tuktoyaktuk Coastlands, western Arctic Canada. Quaternary Science Reviews 24, 681-708. doi:10.1016/j.quascirev.2004.06.008.

Murton, J.B., Frechen, M., Maddy, D., 2007. Luminescence dating of mid- to Late Wisconsinan aeolian sand as a constraint on the last advance of the Laurentide Ice Sheet across the Tuktoyaktuk Coastlands, western Arctic Canada. Canadian Journal of Earth Sciences 44, 857-869. doi:10.1139/E07-015.

Nelson, R.E., Carter, L.D., 1987. Paleoenvironmental analysis of insects and extralimital Populus from an early Holocene site on the Arctic slope of Alaska, U.S.A. Arctic and Alpine Research 19, 230-241.

Pienitz, R., Smol, J.P., Last, W.M., Leavitt, P.R., Cumming, B.F., 2000. Multi-proxy Holocene palaeoclimatic record from a saline lake in the Canadian Subarctic. The Holocene 10, 673-686. doi:10.1191/09596830094935.

Pollard, W.H., 1990. The nature and origin of ground ice in the Herschel Island area, Yukon Territory. Proceedings of the Fifth Canadian Permafrost Conference. Collection Nordicana, Québec, pp. 23-30.

Pollard, W.H., Dallimore, S.R., 1988. Petrographic characteristics of massive ground ice, Yukon Coastal Plain, Canada. Proceedings of the Fifth International Conference on Permafrost, 2-5 August 1988, Trondheim, Norway. Tapir Publishers, pp. 224-229.
Preusser, F., 2003. IRSL dating of K-rich feldspars using the SAR protocol: comparison with independent age control. Ancient TL 21, 17-23.

Preusser, F., Kasper, H.U., 2001. Comparison of dose rate determination using highresolution gamma spectrometry and inductively coupled plasma-mass spectrometry. Ancient TL 19, 17-21.

Rampton, V.N., 1971. Late Quaternary vegetational and climatic history of the SnagKlutlan area, southwest Yukon Territory, Canada. Geological Society of America Bulletin 82, 959-978.

Rampton, V.N., 1982. Quaternary geology of the Yukon Coastal Plain. Geological Survey of Canada Bulletin 317 (49 pp.).

Rampton, V.N., 1988. Quaternary geology of the Tuktoyaktuk coastlands, Northwest Territories. Geological Survey of Canada Memoir 423 (98 pp.).

Reimer, P.J., Baillie, M.G., Bard, E., Bayliss, A., Beck, J.W., Blackwell, P.G., Bronk Ramsey C., Buck, C.E., Burr, G.S., Edwards, R.L., Friedrich, M., Grootes, P.M., Guilderson, T.P., Hajdas, I., Heaton, T.J., Hogg, A.G., Hughen, K.A., Kaiser, K.F., Kromer, B., McCormac, F.G., Manning, S.W., Reimer, R.W., Richards, D.A., Southon, J.R., Talamo, S., Turney, C.S.M., van der Plicht, J., Weyhenmeyer, C.E., 2009. Intcal09 and marine09 radiocarbon age calibration curves, $0-50,000$ years cal BP. Radiocarbon 51, 1111-1150.

Ritchie, J.C., 1984. Past and Present Vegetation of the Far Northwest of Canada. University of Toronto Press, Toronto.

Ritchie, J.C., Cwynar, L.C., 1982. The late-Quaternary vegetation of the north Yukon. In: Hopkins, D.M., Matthews Jr., J.V., Schweger, C.E., Young, S.B. (Eds.), Paleoecology of Beringia. Academic Press, New York, pp. 113-126.

Ritchie, J.C., Hare, F.K., 1971. Late-quaternary vegetation and climate near the arctic tree line of northwestern North America. Quaternary Research 1, 331-342. doi:10.1016/0033-5894(71)90069-X.

Ritchie, J.C., Cwynar, L.C., Spear, R.W., 1983. Evidence from north-west Canada for an early Holocene Milankovitch thermal maximum. Nature 305, 126-128. doi:10.1038/305126a0.

Schell, T.M., Scott, D.B., Rochon, A., Blasco, S., 2008. Late Quaternary paleoceanography and paleo-sea ice conditions in the Mackenzie Trough and Canyon, Beaufort Sea. Canadian Journal of Earth Sciences 45, 1399-1415. doi:10.1139/E08-054.

Schwamborn, G., Meyer, H., Fedorov, G., Schirrmeister, L., Hubberten, H.-W., 2006 Ground ice and slope sediments archiving late Quaternary paleoenvironment and paleoclimate signals at the margins of El'gygytgyn Impact Crater, NE Siberia. Quaternary Research 66, 259-272. doi:10.1016/j.yqres.2006.06.007.

Smith, A.J., Delorme, L.D., 2010. Chapter 19 - Ostracoda. In: Thorp, J.H., Covich, A.P. (Eds.), Ecology and Classification of North American Freshwater Invertebrates (Aquatic Ecology). Elsevier, London, pp. 725-771. doi:10.1016/B978-0-12374855-3.00019-4.

Spear, R.W., 1993. The palynological record of Late-Quaternary arctic tree-line in northwest Canada. Review of Palaeobotany and Palynology 79, 99-111.

St-Jean, M., Lauriol, B., Clark, I.D., Lacelle, D., Zdanowicz, C., 2011. Investigation of icewedge infilling processes using stable oxygen and hydrogen isotopes, crystallography and occluded gases $\left(\mathrm{O}_{2}, \mathrm{~N}_{2}, \mathrm{Ar}\right)$. Permafrost and Periglacial Processes 22 49-64. doi:10.1002/ppp. 680.

Stuiver, M., Reimer, P.J., 1993. Extended ${ }^{14} \mathrm{C}$ data base and revised CALIB $3.0{ }^{14} \mathrm{C}$ age calibration program. Radiocarbon 35, 215-230.

Swain, F.M., 1963. Ostracoda from the Gubik Formation, Arctic Coastal Plain, Alaska. Journal of Paleontology 37, 798-834.

van Everdingen, R. (Ed.), 1998. Revised May 2005. Multi-Language Glossary of Permafrost and Related Ground-Ice Terms. National Snow and Ice Data Center/World Data Center for Glaciology, Boulder, CO.

Vardy, S.R., Warner, B.G., Aravena, R., 1997. Holocene climate effects on the development of a peatland on the Tuktoyaktuk Peninsula, Northwest Territories. Quaternary Research 47, 90-104. doi:10.1006/qres.1996.1869.

Vardy, S.R., Warner, B.G., Aravena, R., 1998. Holocene climate and the development of a subarctic peatland near Inuvik, Northwest Territories, Canada. Climatic Change 40, 285-313. doi:10.1023/A:1005473021115.

Vardy, S.R., Warner, B.G., Turunen, J., Aravena, R., 2000. Carbon accumulation in permafrost peatlands in the Northwest Territories and Nunavut, Canada. The Holocene 10, 273-280. doi:10.1191/095968300671749538.

Vermaire, J.C., Cwynar, L.C., 2010. A revised late-Quaternary vegetation history of the unglaciated southwestern Yukon Territory, Canada, from Antifreeze and Eikland ponds. Canadian Journal of Earth Sciences 47, 75-88. doi:10.1139/E09-075.

Viau, A.E., Gajewski, K., Sawada, M.C., Bunbury, J., 2008. Low- and high-frequency climate variability in eastern Beringia during the past 25000 years. Canadian Journal of Earth Sciences 45, 1435-1453. doi:10.1139/E08-036.

Yokoyama, Y., Lambeck, K., De Deckker, P., Johnston, P., Fifield, L.K., 2000. Timing of the Last Glacial Maximum from observed sea-level minima. Nature 406, 713-716. doi:10.1038/35021035.

Zazula, G.D., Hare, P.G., Storer, J.E., 2009. New radiocarbon-dated vertebrate fossils from Herschel Island: implications for the palaeoenvironments and glacial chronology of the Beaufort Sea coastlands. Arctic 62, 273-280. 